\title{
Ediacaran emerald mineralization in Northeastern Brazil: the case of the Fazenda Bonfim Deposit
}

\author{
Judiron Santos Santiago ${ }^{1,2}$ (D), Valmir da Silva Souza ${ }^{3 *}$ (D), Elton Luiz Dantas ${ }^{3}$ (D), Claudinei Gouveia de Oliveira ${ }^{3}$ (D)
}

\begin{abstract}
The Fazenda Bonfim emerald deposit lies within the Seridó Belt. It is a classic example of deposit formed through metasomatic interactions between Be-rich granite intrusions and $\mathrm{Cr}( \pm \mathrm{V})$-rich mafic-ultramafic rocks. The setting of the emerald mineralization was built under strong strikeslip dynamics, which produced serpentinization and talcification of mafic-ultramafic host-rocks, and was followed by syn-kinematic emplacement of Be-rich albite granite, favoring hydrothermal/metasomatic processes. The structural control and lithological-contrast were fundamental to the fluid flow and the best ore-shoot geometry, developed in the S-foliation intra-plane at the contact zone (phlogopite hornfels) between mafic-ultramafic rocks and the albite granite. Subsequently, an albitization process, linked to the final-stage of magmatic crystallization, led to an overall mineralogical and chemical change of the albite granite. $207 \mathrm{U}-235 \mathrm{~Pb}$ data revealed inheritance ages from Archean to Neoproterozoic and a crystallization age of $561 \pm 4 \mathrm{Ma}$ for albite granite. However, 40Ar/39Ar data revealed plateau age of $553 \pm 4 \mathrm{Ma}$ for phlogopite hornfels, interpreted as the closure time for the metasomatic event responsible for the nucleation and growth of emerald crystals. The short interval of time between $\mathrm{U}-\mathrm{Pb}$ and $\mathrm{Ar}-\mathrm{Ar}$ data indicates an intense, but not protracted, metasomatic history, probably due to low volume of intrusive magma.
\end{abstract}

KEYWORDS: Fazenda Bonfim emerald deposit; Seridó Belt; geology; geochemistry; U-Pb and Ar-Ar geochronology.

\section{INTRODUCTION}

The northeastern region of Brazil hosts numerous occurrences of beautiful and exotic varieties of gem-quality minerals linked to different generations of granitic pegmatite bodies emplaced during to the Brasiliano orogeny (800-500 Ma), under strong structural-tectonic control (Jardim de Sá et al. 1981, Silva et al. 1995, Angelim et al. 2006, Beurlen et al. 2014, Cavalcante et al. 2016). However, the origin, evolution and fertility of these granitic magmatism are not well understood due to the lack of petrological studies. Emerald deposits of economic importance have been recognized in this region since the mid-twentieth century, especially in the state of Bahia, but other less important deposits are registered in the states of Ceará and Rio Grande do Norte. These deposits were the result of metasomatic interaction between fluids exsolved from granitic pegmatite and metavolcano-sedimentary rocks, mainly basic-ultrabasic composition, affected by complex folding and deformation (Giuliani et al. 1990, Baumgartner et al. 2006, Beurlen et al. 2014, Oliveira \& Ali 2011).

The Fazenda Bonfim emerald deposit is located in the central part of the state of Rio Grande do Norte (Fig. 1A).

\footnotetext{
${ }^{1}$ Programa de Pós-Graduação em Geologia, Instituto de Geociências, Universidade de Brasília - Brasília (DF), Brazil.

E-mail: judirongeo@yahoo.com.br

${ }^{2}$ Companhia Baiana de Pesquisa Mineral - Salvador (BA), Brazil. ${ }^{3}$ Instituto de Geociências, Universidade de Brasília - Brasília (DF), Brazil.E-mails: vsouza@unb.br, elton@unb.br, gouveia@unb.br

${ }^{*}$ Corresponding author
}

It was discovered in 2005 during mineral prospecting for $\mathrm{Cr}$ and $\mathrm{Ni}$ associated with ultramafic rocks. Currently, the Vale Verde Mining Company, which holds the exploration rights, is reassessing the mine in order to resume production. However, this region is geochemically anomalous for $\mathrm{Cr}$, $\mathrm{Be}, \mathrm{K}$ and $\mathrm{Li}$, as well as for $\mathrm{Mg}, \mathrm{Na}, \mathrm{Ni}$ and $\mathrm{V}$, and therefore favorable for the occurrence of additional emerald deposits (Scholz et al. 2010).

In the Fazenda Bonfim deposit, emerald crystals occur at the contact zone between Be-rich albitized granitic body and ultrabasic rocks, mainly enclosed in irregular lens-shaped of phlogopite schist (phlogopite hornfels). In this place, emeralds typically consist of short crystals with concentric growth zones ranging from light to medium-dark bluish green. Their chemical composition is characterized by relatively high amounts of $\mathrm{Mg}$ and low amounts of $\mathrm{Na}$, with $\mathrm{Cr}, \mathrm{Fe}$ and $\mathrm{V}$ as the main chromophore elements. There are also traces of $\mathrm{Ca}, \mathrm{K}, \mathrm{Cs}$, Li, P, Sc, Ti, Mn, Co, Ni, Zn, Ga and Rb (Cavalcanti Neto \& Barbosa 2007, Zwaan et al. 2012, Santiago et al. 2018). Additionally, stable isotope and fluid inclusion studies indicated an igneous-metasomatic source, as well as trapping conditions between $375-430^{\circ} \mathrm{C}$ and $200-600$ bars for emerald components (Santiago et al. 2018).

The geological setting of the Fazenda Bonfim emerald deposit is presented in this paper, focusing on the petrography, geochemistry and geochronology (U-Pb and $\mathrm{Ar}-\mathrm{Ar}$ ) of the identified lithologies, as well as the ore-shoot structural control. These data are complementary parts of the research presented by Santiago et al. (2018), which provides the basis of our genetic proposal for emerald deposits linked to the Neoproterozoic Brasiliano orogeny in northeastern Brazil. 


\section{ANALYTICAL METHODS}

Conventional petrographic investigations were performed at the microscopy laboratory of the University of Brasilia. The preparation of the samples for geochemistry analyses, applying crushing and pulverizing in a tungsten carbide shatter box, was done at the Isotope Geology laboratories at the University of Brasília. Whole rock powders (ca. $10 \mathrm{mg}$ ) were sent to ACME Analytical Laboratories Ltd., Vancouver, Canada. The Inductively Coupled Plasma-Emission Spectrometry (ICP-ES) method was utilized for major and minor elements analysis, while for trace and rare
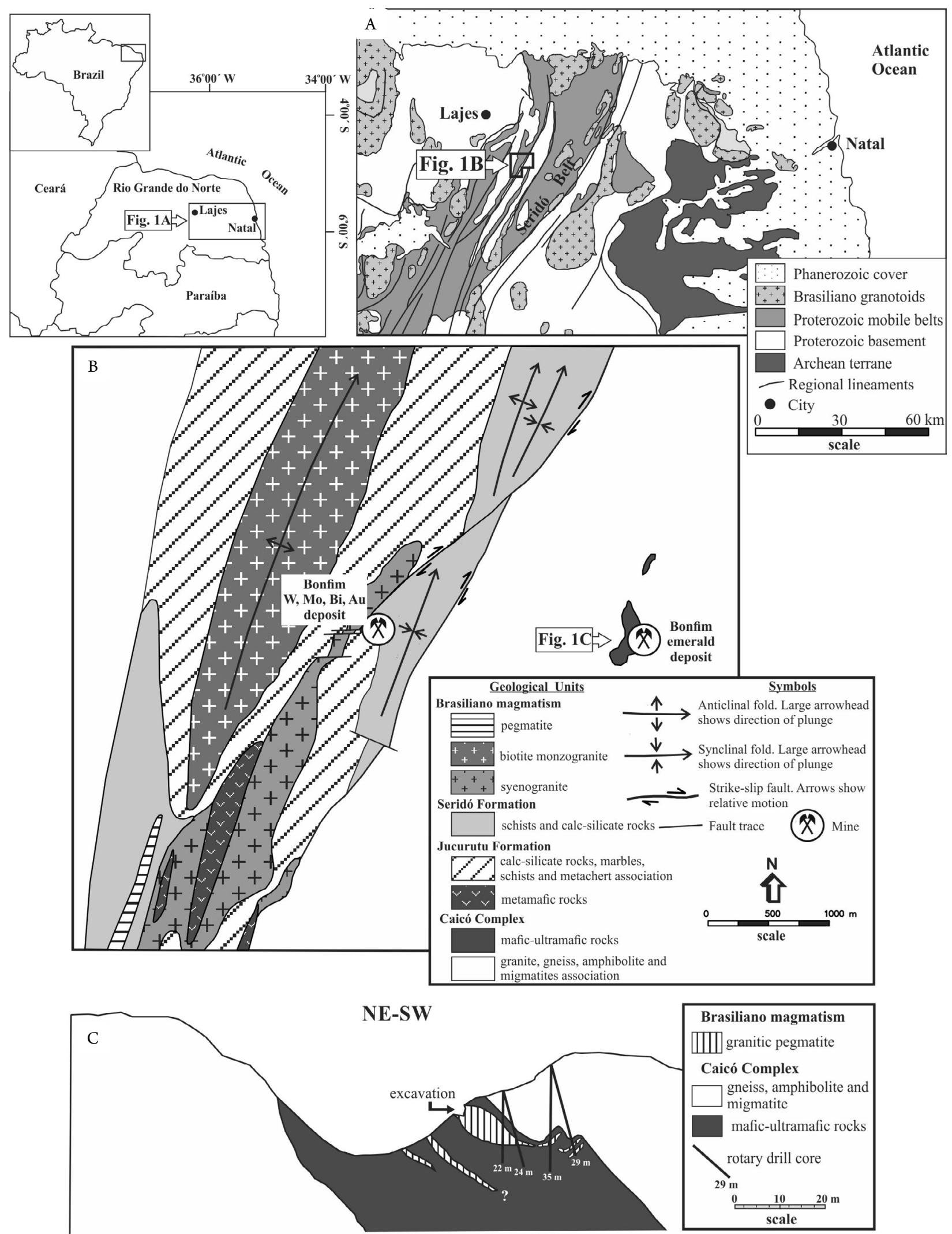

Figure 1. Geological and location maps of the Fazenda Bonfim emerald deposit area. (A) Regional geological map (adapted from Cavalcanti Neto \& Barbosa 2007); (B) Local geological map. Observe the distribution of W, Mo, Bi, Au and emerald deposits in the area (adapted from Nosso Senhor do Bonfim Mining Company internal report); (C) Geological cross-section of the excavation area of the mine inferred from geological mapping and borehole data. The vertical scale is exaggerated (Santiago 2017). 
earth elements (REE), the Inductively Coupled Plasma-Mass Spectrometry (ICP-MS) method was applied.

${ }^{207} \mathrm{U}-{ }^{235} \mathrm{~Pb}$ isotopic analyses on zircons were carried out at the Isotope Geology laboratories of the University of Brasília, under the supervision of Professor E. L. Dantas. They were carried out by LA-MC-ICP-MS, following the analytical procedure described by Bühn et al. (2009). Zircon concentrates were extracted using conventional gravimetric and magnetic separation techniques. Zircon grains were selected under a binocular microscope to obtain fractions of similar size, shape and color. For in situ $\mathrm{U}-\mathrm{Pb}$, hand-picked zircon grains were mounted in epoxy blocks and polished. Backscattered electron images were obtained in order to investigate the internal structures of the zircon crystals prior to the analysis. The laser microprobe is a New Wave UP213 Nd:YAG laser $(\lambda=213 \mathrm{~nm})$, connected with a Thermo Finnigan Neptune Multi-collector ICP-MS. Helium was used as the carrier gas and mixed with argon before entering the ICP. The laser was run at a frequency of $10 \mathrm{~Hz}$ and energy of $\sim 100 \mathrm{~mJ} / \mathrm{cm}^{2}$ with a spot of $30 \mu \mathrm{m}$ for $\mathrm{U}-\mathrm{Pb}$ dating and $40 \mu \mathrm{m}$ for $\mathrm{Hf}$ isotopic analyses. $\mathrm{U}-\mathrm{Pb}$ diagrams and age calculations were done using ISOPLOT version 3.0 (Ludwig 2003) and errors for isotopic ratios are presented at the $1 \sigma$ level.

${ }^{40} \mathrm{Ar} /{ }^{39} \mathrm{Ar}$ isotopic analyses on mica samples from phlogopite hornfels were carried out at the Isotopic Geology laboratories at Queen's University in the Department of Geological Sciences \& Geological Engineering in Ontario (Canada), under the supervision of Professor D. A. Archibald. Mineral samples for ${ }^{40} \mathrm{Ar} /{ }^{39} \mathrm{Ar}$ analyses were obtained from hand samples that were grounded by mortar and pestle, followed by a hand-picked selection that was placed under a binocular microscope to guarantee a high purity of mica flakes. ${ }^{40} \mathrm{Ar}-{ }^{39} \mathrm{Ar}$ isotopic analysis followed the analytical procedure described by Roddick (1983). Mineral concentrates were then irradiated for about 40 hours in a McMaster nuclear reactor. A specific $8 \mathrm{~W}$ Lexel 3500 ion laser (Ar), a MAP216 mass spectrometer with a Baur-Signer source and a multicollector electron were employed. Ages and errors were corrected using the formulas proposed by Steiger and Jäger (1977) and Dalrymple et al. (1981). The ${ }^{40} \mathrm{Ar}-{ }^{39} \mathrm{Ar}$ ages and errors shown represent an analytical precision of $2 \sigma$ or $0.5 \%$, matching plateau variation form spectrum (McDougall \& Harrison 1988). The ages obtained were referenced to the standard $\mathrm{Hb} 3 \mathrm{Gr}$ (hornblende) from 1,072 Ma (Roddick 1983).

\section{REGIONAL GEOLOGICAL SETTING}

A large part of northeastern Brazil lies within the regional geotectonic unit named the Borborema Province (Almeida et al. 1981). This geotectonic province was formed through the aggregation of several crustal blocks during the Paleo- and Mesoproterozoic times, and restructured subsequently in the late Neoproterozoic, during the Brasiliano orogeny (Caby et al. 1991, Jardim de Sá et al. 1995, Van Schmus et al. 1995, Brito Neves et al. 2000, 2014, Neves 2003).

During the Brasiliano orogeny, a strong strike-slip tectonic regime led to the generation of dextral wrench/strikeslip fault systems that divided the Borborema Province into different domains and/or terranes. In this geotectonic context, the state of Rio Grande do Norte hosts the Jaguaribeano, the Rio Piranhas-Seridó and the São José do Campestre tectonostructural domains. Most of the gem-quality mineral occurrences are located within the Rio Piranhas-Seridó domain, being part of the Neoproterozoic Seridó Belt (Fig. 1A).

The Archean-Paleoproterozoic basement of the Seridó Belt is composed of migmatites, granite-gneisses, metagranites, amphibolites, metamafic-metaultramafic rocks and metavolcano-sedimentary sequences grouped within two regional units known as the São José do Campestre Massif and the Caicó Complex (Jardim de Sá 1994, Dantas 1997, Dantas et al. 2004, 2013, Souza et al. 2007). Neoproterozoic supracrustal units were deposited on the basement, making up the Seridó Group, which is composed of diverse metasedimentary sequences, subdivided, from base to top, into the Jucurutu, Equador and Seridó formations (Angelim et al. 2006, Van Schmus et al. 2003, Caby et al. 1995).

During the Neoproterozoic, pre- to post-Brasiliano orogeny granite pegmatite magmas intruded the basement rocks and Seridó Group units, under a clear structural-tectonic control. This voluminous magmatism (580-570 Ma) has been divided into phases or suites, consisting of medium to coarse-grained granitoids and Be-Ta-Li-Sn, gem-bearing pegmatite bodies (Baumgartner et al.2006, Beurlen et al.2009, 2014). These rocks present variable degrees of deformation and include an expanded granitoid series ranging from gabbro/diorite to alkali-feldspar syenogranite/syenite, and rare albite granite (Jardim de Sá et al. 1981, Sial 1986, Agrawal 1992, Ferreira et al. 1998, Nascimento et al. 2000). However, petrological information on the source, depth and age of these magmas are still incomplete.

The great variety of granitic magmas in the Seridó Belt has been the focus of different classification schemes, linked to evolutionary history of the Borborema Province. Based on tectonic position (syn- to late-tectonic), regional distribution and some geochronological data, these granite pegmatite magmas may be categorized into phases G1 to G4 (Jardim de Sá et al. 1981), or simply distinguished as highly deformed and weakly deformed or undeformed pegmatite-granitic suites (Agrawal 1992). On the other hand, the mineralogical variety and the internal texture arrangement, may be used to distinction between homogeneous (usually sterile) and heterogeneous (fertile for $\mathrm{Be}-\mathrm{Li}$ and $\mathrm{Nb}-\mathrm{Ta}-\mathrm{Sn}$ ) intrusions, which are inserted into the peraluminous LCT-type granite pegmatite (Silva et al. 1995, Baumgartner et al. 2006, Beurlen et al.2009, 2014). However, the understanding about the geological processes linked to the genesis, evolution and fertilization of these granitic magmas is still controversial.

Most of these granite pegmatite magmas occur as intrusions within metasedimentary sequences of the Seridó Group, emplaced at the end of the Brasiliano orogeny and crystallized between $600-400^{\circ} \mathrm{C}$ and 4-3 kbar (Beurlen et al. 2001, 2014, Soares 2004, Baumgartner et al. 2006). This geological framework may favor the formation of ore deposits linked to metasomatic interactions between wall rocks $v s$. granitic intrusion. In the study area, two examples of metasomatic ore deposits are found (Fig. 1B): 
- the $\mathrm{W}-\mathrm{Mo}-\mathrm{Bi} \pm \mathrm{Au}$ skarn deposit developed at the contact zone between granitoids and marble or calc-silicate rocks from Seridó Group (Souza Neto et al. 2008);

- the emerald deposit at the contact zone between granitoids and mafic-ultramafic rocks of the Caicó Complex Basement (Cavalcanti Neto \& Barbosa 2007, Santiago et al. 2018).

\section{LOCAL GEOLOGICAL SETTING}

The Fazenda Bonfim emerald deposit lies within the Caicó Complex Basement (Figs. 1B and 1C). At this location, the basement is mainly composed of orthogneiss, augen-gneiss and interfingered amphibolite lenses, as well as mafic-ultramafic lenticular bodies. The mining site was developed at the contact between lenticular mafic-ultramafic and Be-rich albite granite bodies (Fig. 2A). However, a small part of these granites also intrudes orthogneiss and augen-gneiss. In the following, the main petrographic and structural characteristics of these lithologies are described.

\section{Gneiss and Amphibolite}

The orthogneiss and augen-gneiss are dominant in the study area, showing light pink to reddish-gray color and medium to coarse grained, with an irregular to anastomosed banded structure dipping and striking in average $48^{\circ} / 310^{\circ} \mathrm{Az}$ (Fig. 2B). They have granolepidoblastic to mylonitic textures, alternating
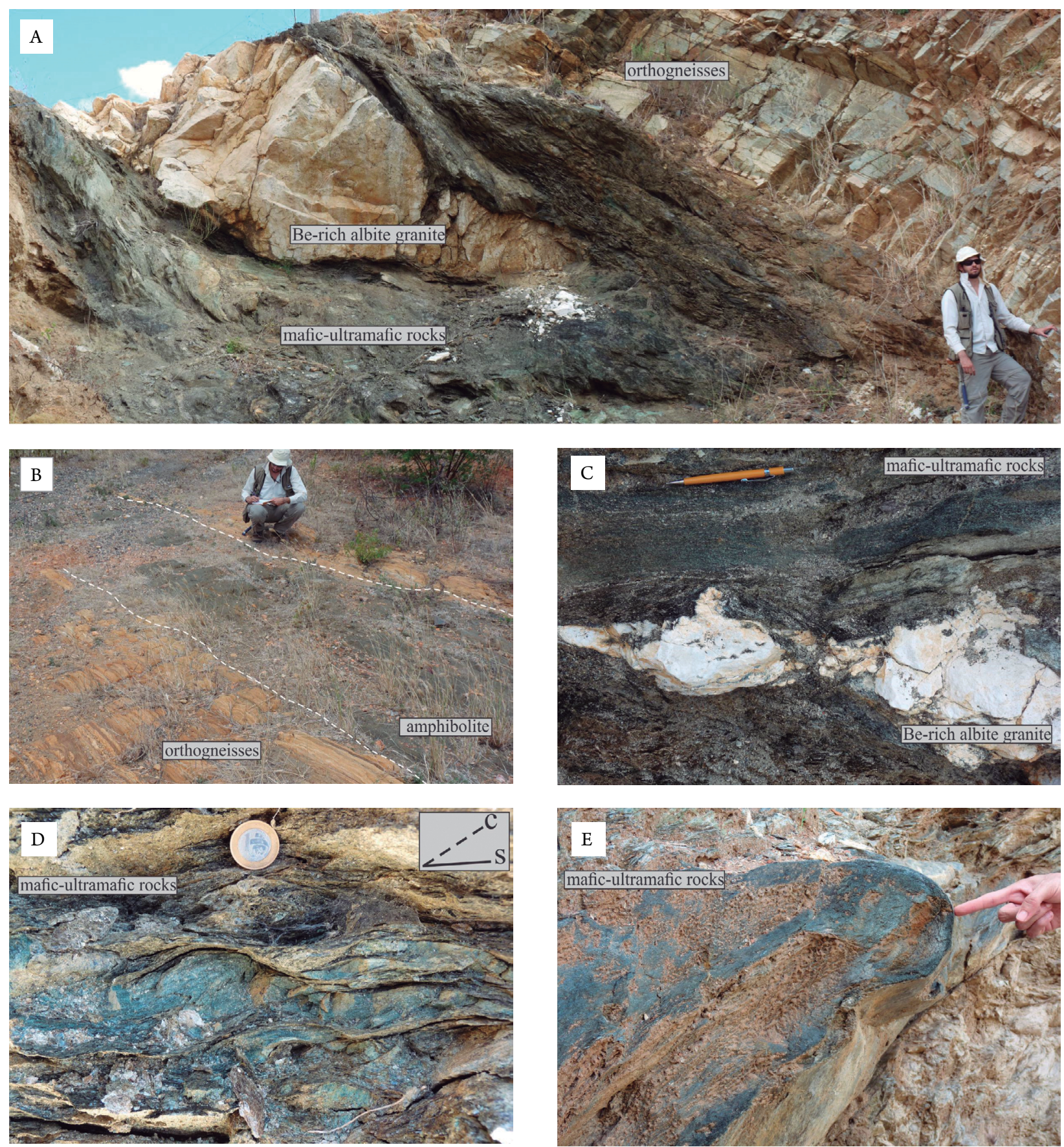

Figure 2. Geological framework at the excavation place of the Fazenda Bonfim emerald deposit. (A) Lenticular Be-rich albite granite body intrusive into the mafic-ultramafic rocks and orthogneiss; (B) Orthogneiss interfingered with amphibolite lens from Caicó Complex Basement; (C) Granitic melt filled dilation intra-folial sites with formation of pinch-and-swell structures; (D) S-C fabric with intra-plane angle between $25^{\circ}-30^{\circ}$ associated to the shear bands (dashed line orientation); (E) Recumbent fold with sloping axial plane verging toward the NW. 
quartz-feldspar felsic bands (containing asymmetric porphyroclasts) and mafic bands formed of biotite + amphibole aggregate, which host the majority of accessory minerals (zircon, apatite, monazite, titanite and opaque minerals). The amphibolite lenses, mainly embedded in orthogneiss, have NE-SW orientation (Fig. 2B), are fine- to medium-grained, and show dark green color and anastomosed mylonitic internal foliation. Occasionally, they exhibit disharmonic- and drag-fold styles, as well as metric-sized boudins structures. They are composed of amphibole \pm biotite and opaque minerals distributed in a nematoblastic texture arrangement.

\section{Mafic-ultramafic Rocks}

These lithologies have lenticular geometry dipping $40-45^{\circ}$ to NW and internally host heterogeneous deformation mostly under ductile strain, marked by several fold styles (disharmonic, intrafolial, recumbent, ptygmatic and parasitic), boudins, shear zones, foliations and lineations. These rocks are still crossed by some faults and fractures, probably linked to a later stage.

These ductile deformational structures were developed under a dominant dextral shear regime. Intra-foliation dilating sites were filled by fractioned granitic melts, generating pods and pinch-and-swell structures (Figs. 2A and 2C). The mylonitic foliation or S-foliation (schistosity plane) is dominant, has an anastomosed geometric pattern and orientation of around $40^{\circ} / 305^{\circ} \mathrm{Az}$. Occasionally, a discreet C-foliation (shear plane) linked to shear band and oblique to the schistosity plane can be identified. They produce $S$-C fabric with intra-plane angle between $30^{\circ}-40^{\circ}$ (Fig. 2D). The style of folds presents a complex geometric relationship. In general, they have a mean weighted plunge in the fold axes of $30^{\circ} / 213^{\circ} \mathrm{Az}$, but a wide range of plunge between $10^{\circ}-50^{\circ}$ is observed, with a sloping axial plane verging toward the NW (Fig. 2E). The lineation (mineral stretching type) confined to the $\mathrm{S}$-foliation plane is also observed, whose orientation is of around $10^{\circ} / 220^{\circ} \mathrm{Az}$. It is subparallel to the fold axes and coincides with the orientation of the $c$-axis growth of emerald crystal (Fig. 3A).

In general, these lithologies show light-to-dark green and blackish-green color, medium-to-coarse grained, with various degrees of serpentinization. They present variable proportion of serpentine and talc, associated with tremolite, actinolite, biotite and phlogopite, forming a mesh or bastite/fibrous-interlaced and lepido-nematoblastic microtexture (Figs. 3B and $3 \mathrm{C}$ ). Magnetite, chromite, pyrite, chalcopyrite, ilmenite and rare beryl are the accessory minerals, while garnierite and chlorite occur as substitution minerals. Occasionally olivine and pyroxene ghost- or relics/skeletal-phenocrysts are observed (Fig. 3D).

At the contact between mafic-ultramafic and Be-rich albite granite, an irregular lens-shaped medium to coarse-grained phlogopite schist occur, which can be named as phlogopite hornfels (Fig. 3E). This lithology is black and almost entirely composed of euhedral to subhedral phlogopite aggregates. Usually, phlogopite crystals show size larger than $5 \mathrm{~mm}$, distributed in a lepidoblastic microtexture, frequently surrounding emerald short-crystals (Santiago et al. 2018). This lithological type has been named as "blackwall" zone in other emerald deposits formed by metasomatic interaction (e.g., Grundmann \& Morteani 1989, Andrianjakavah et al. 2009). However, the intensity of this metasomatic transformation is apparently controlled by the degree of granitic melt $v s$. wall rock interaction.

\section{Be-rich albite granite}

This lithology has lenticular to pod-shaped bodies with deformation concentrated at the edges and undeformed cores (Fig. 2A). They show color ranging from white to an off-white cream, medium to coarse-grained granoblastic to heterogranular texture and contain disseminated euhedral to subhedral beryl phenocrysts with wide range in size $0.3-2.5 \mathrm{~cm}$ (Fig. 3F). The albite granites are composed essentially of albite $\left(\mathrm{An}_{4-8}\right)$, quartz and muscovite, with rare interstitial microcline, as well as zircon, apatite and opaque as accessory minerals. In the core, an albitized portion marked by albite glomerophyric texture is often observed, while transecting quartz-veinlets become more abundant toward the edges.

\section{LITHOCHEMISTRY}

In this topic, bulk chemical-composition data of the mafic-ultramafic and Be-rich albite granite are presented (Tab. 1). The analyzed unweathered samples from drilling cores were selected.

Lithochemical data from mafic-ultramafic rocks reveals contents of $\mathrm{SiO}_{2}=36-42$ wt. $\%, \mathrm{Al}_{2} \mathrm{O}_{3}=1.2-2.5$ wt.\%, $\mathrm{Fe}_{2} \mathrm{O}_{3 \text { tot. }}=7.53-8.76$ wt.\%, and $\mathrm{MgO}=31.30-36.10$ wt.\%, low $\mathrm{TiO}_{2}, \mathrm{MnO}, \mathrm{CaO}, \mathrm{Na}_{2} \mathrm{O}, \mathrm{K}_{2} \mathrm{O}$, and $\mathrm{P}_{2} \mathrm{O}_{5}<1 \mathrm{wt}$.\%, and high LOI $=13.40-16.40 \mathrm{wt} . \%$, evidencing the effective hydration of these lithologies. They are enriched of $\mathrm{Cr}$, $\mathrm{Ni}, \mathrm{V}$, and depleted of REE, large-ion lithophile- (LIL) and high field strength- (HFS) elements.

On the chondrite-normalized, multi-elements diagram $\mathrm{Ba}, \mathrm{K}, \mathrm{Sr}, \mathrm{Ti}, \mathrm{Zr}$ show negative anomalies, and $\mathrm{Rb}, \mathrm{Nb}, \mathrm{Nd}, \mathrm{Sm}$ show positive ones (Fig. 4A). Sample JAQ4, collected near the contact zone between mafic-ultramafic $v$ s. Be-rich albite granite (blackwall zone), is different from the other mafic-ultramafic samples, showing anomalous contents of $\mathrm{Na}, \mathrm{K}, \mathrm{Rb}$ and $\mathrm{Cs}$, which are attributed to metasomatic effects (Tab. 1). In addition, on the chondrite-normalized REE patterns (Fig. 4B), there is a weak to moderate degree of fractionation for light rare earth elements (LREE) $\left(\mathrm{La}_{\mathrm{N}} / \mathrm{Sm}_{\mathrm{N}} v s \mathrm{Sm}_{\mathrm{N}}=1.93-5.48\right)$ and heavy rare earth elements (HREE) $\left(\mathrm{Gd}_{\mathrm{N}} / \mathrm{Yb}_{\mathrm{N}} v s \mathrm{Yb}_{\mathrm{N}}=\right.$ $1.12-2.58)$, separated by a small negative Eu anomaly $(\mathrm{Eu} /$ $\left.\mathrm{Eu}^{*}=0.60-0.80\right)$. Exceptions are the JAQ 2 and JAQ 5 samples (Tab. 1). The first sample is enriched from intermediate REE to HREE, with a ratio of $(\mathrm{La} / \mathrm{Yb})_{N}=0.66$, showing a lightly concave-downward REE pattern. This sample shows anomalous content of $\mathrm{Be}, \mathrm{Rb}, \mathrm{Cs}, \mathrm{Ba}, \mathrm{Sr}, \mathrm{U}$, and $\mathrm{Y}$, which are linked to an effective metasomatic process. The second sample exhibits strong depletion of REE, attributed to its advanced stage of serpentinization.

Be-rich albite granite show lithochemical differences caused by variable proportions of plagioclase aggregates linked to different stages of albitization (Tab. 1). The JM-11A, JM-12, JAQ-6 samples are representative of granoblastic to heterogranular 
albite granite partially albitized facies (main lithology), while the JM-10 and JAQ- 8 samples represent the albitized facies. In general, these rocks show peraluminous composition (Fig. 4C). The JM-11A, JM-12, JAQ-6 samples have a tonalitic geochemical composition (Fig. 4D), while the JM-10 e JAQ-8 samples show major chemical elements $\left(\mathrm{SiO}_{2}, \mathrm{Al}_{2} \mathrm{O}_{3}, \mathrm{CaO}\right.$ e $\left.\mathrm{Na}_{2} \mathrm{O}\right)$ combining within the composition of a plagioclase series (oligoclase-andesine members; e.g., Deer et al. 1992). The JM-11A, JM-12, JAQ-6 samples have high amounts of $\mathrm{Nb}$ and $\mathrm{Ta}( \pm \mathrm{U})$, which are indicative of presence of $\mathrm{Nb}$-Ta oxides as opaque accessory minerals in these lithologies. Their ratios $\mathrm{Nb} / \mathrm{Ta}=$ $1.08-1.65$ and $\mathrm{Zr} / \mathrm{Hf}=9-13.5$ are indicative for fertile raremetal mineralization, according to geochemical parameters suggested by Ballouard et al. (2016).
On the other hand, the JM-10 and JAQ-8 samples have high amounts of Be and Sr related to the presence of beryl and plagioclase, while the $\mathrm{Nb}$ and Ta loss may be linked to shortages of $\mathrm{Nb}$-Ta oxide minerals in these lithologies. Therefore, mineralogy and mineral-chemistry studies on accessory mineral assemblage of the Fazenda Bonfim albitite still need to be performed. The uncommon contents of $\mathrm{Ni}$ and $\mathrm{V}$ in these rocks reflect a geochemical imbalance due to metasomatism. In general, the albite granite samples show similar patterns on the chondrite-normalized multi-elements plot, marked by negatives anomalies in $\mathrm{Ba}, \mathrm{Ce}, \mathrm{Nd}, \mathrm{P}, \mathrm{Sm}, \mathrm{Ti}$, and positives anomalies in $\mathrm{Rb}, \mathrm{Sr}, \mathrm{Zr}, \mathrm{Hf}$ (Fig. 4E). However, less albitized samples are distinguished by strong positive $\mathrm{Nb}$ anomaly and slight enrichment in HREE compared to the strongly albitized samples.
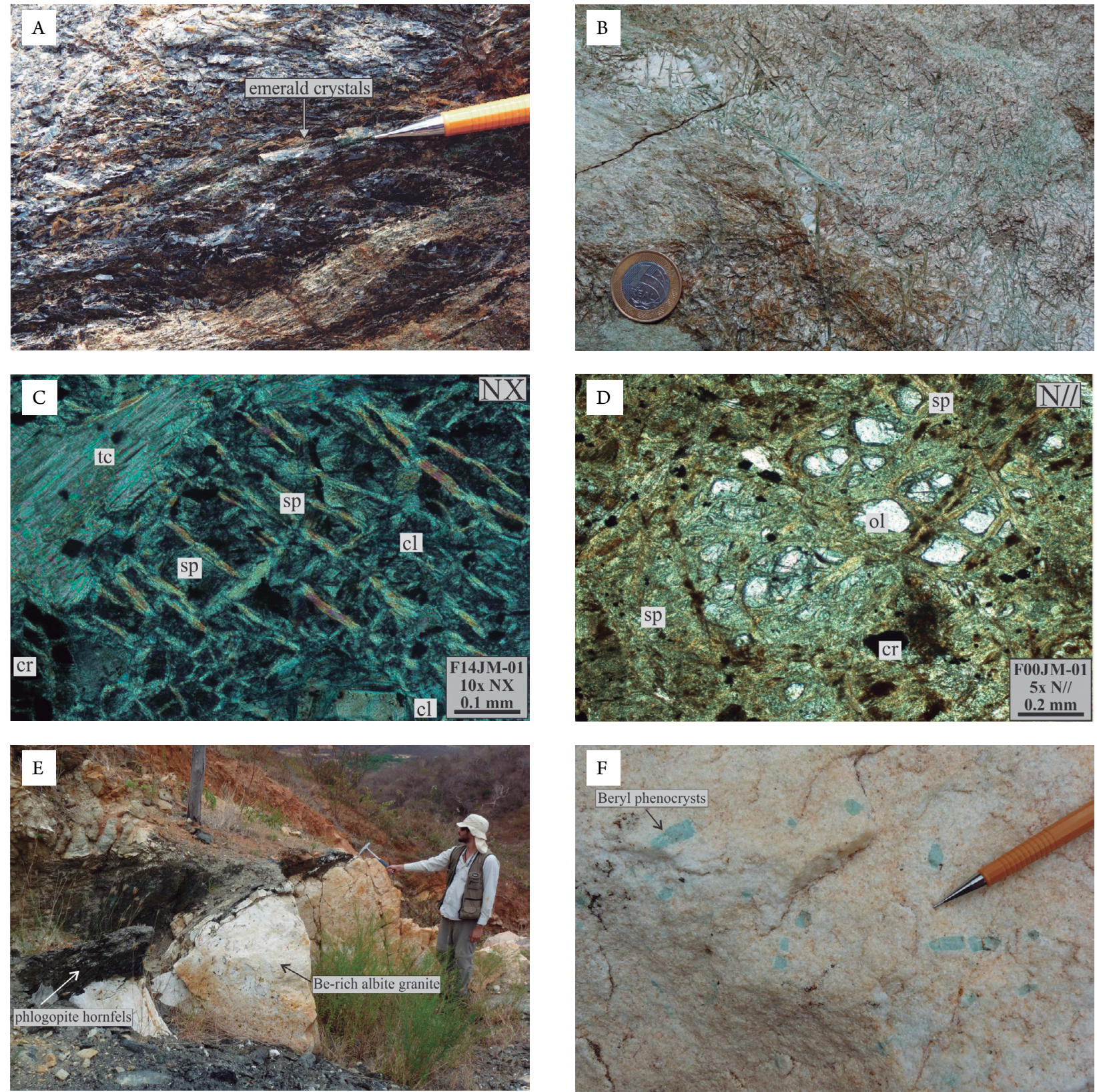

Cl: chlorite; cr: chromite; ol: olivine; sp: serpentine; tc: talc; NX: crossed nicols; N//: parallel nicols.

Figure 3. (A) Emerald crystals developed on S-foliation plane, with the c-axis growth subparallel to L-lineation and fold axes, indicating an important role of the fluid flow to the ore-shoot geometry; (B) Euhedral to subhedral elongate tremolite crystals (tremolite-bastites) in serpentinite; (C) Bastites in matrix of mesh microtexture in serpentinite; (D) Olivine relics/skeletal phenocrysts in serpentinite; (E) Phlogopite hornfels located at the contact zone between mafic-ultramafic rocks and Be-rich albite granite. These are the main sites that host emerald mineralization; (F) Macroscopic appearance of the Be-rich albite granite containing beryl phenocrysts. 
Table 1. Whole-rock geochemical compositions of the mafic-ultramafic rocks and Be-rich albite granite facies.

\begin{tabular}{|c|c|c|c|c|c|c|c|c|c|c|c|}
\hline \multirow{2}{*}{$\begin{array}{l}\text { Lithologies } \\
\text { Samples }\end{array}$} & \multicolumn{6}{|c|}{ Mafic-ultramafic } & \multicolumn{5}{|c|}{ Acid-pegmatite } \\
\hline & JAQ-1 & JAQ-2 & JAQ-3 & JAQ-4 & JAQ-5 & JAQ-7 & JM-11A & JM-12 & JAQ-6 & JM-10 & JAQ-8 \\
\hline $\mathrm{SiO}_{2}$ (wt. \%) & 40.16 & 41.88 & 37.84 & 40.02 & 36.37 & 40.64 & 75.05 & 74.62 & 74.77 & 62.45 & 62.08 \\
\hline $\mathrm{TiO}_{2}$ & 0.06 & 0.03 & 0.05 & 0.07 & 0.03 & 0.05 & $<0.01$ & 0.03 & 0.03 & $<0.01$ & $<0.01$ \\
\hline $\mathrm{Al}_{2} \mathrm{O}_{3}$ & 2.27 & 1.48 & 1.74 & 2.52 & 1.18 & 1.60 & 14.83 & 14.94 & 14.86 & 23.06 & 23.69 \\
\hline $\mathrm{Fe}_{2} \mathrm{O}_{3 \text { tot }}$ & 8.14 & 8.13 & 7.95 & 7.78 & 7.53 & 8.76 & 0.08 & 0.36 & 0.47 & 0.06 & 0.09 \\
\hline $\mathrm{MnO}$ & 0.10 & 0.17 & 0.10 & 0.08 & 0.10 & 0.08 & $<0.01$ & 0.02 & 0.01 & $<0.01$ & $<0.01$ \\
\hline $\mathrm{MgO}$ & 32.76 & 31.30 & 34.56 & 32.99 & 36.10 & 32.64 & $<0.01$ & 0.07 & 0.35 & 0.08 & 0.10 \\
\hline $\mathrm{CaO}$ & 0.02 & 0.18 & 0.03 & 0.02 & 0.47 & 0.01 & 1.73 & 1.84 & 1.77 & 4.71 & 4.71 \\
\hline $\mathrm{Na}_{2} \mathrm{O}$ & $<0.01$ & 0.03 & $<0.01$ & 0.07 & $<0.01$ & $<0.01$ & 6.68 & 6.65 & 6.58 & 8.13 & 8.62 \\
\hline $\mathrm{K}_{2} \mathrm{O}$ & 0.01 & 0.03 & $<0.01$ & 1.32 & $<0.01$ & $<0.01$ & 0.4 & 0.44 & 0.45 & 0.38 & 0.46 \\
\hline $\mathrm{P}_{2} \mathrm{O}_{5}$ & $<0.01$ & $<0.01$ & $<0.01$ & $<0.01$ & $<0.01$ & $<0.01$ & 0.02 & 0.02 & $<0.01$ & 0.01 & $<0.01$ \\
\hline LOI & 14.80 & 15.10 & 16.00 & 13.40 & 16.40 & 14.50 & 1 & 0.7 & 0.50 & 0.8 & 0.40 \\
\hline Total & 99.47 & 99.47 & 99.43 & 99.45 & 99.41 & 99.46 & 99.78 & 99.69 & 99.78 & 99.71 & 99.79 \\
\hline $\mathrm{Be}(\mathrm{ppm})$ & 3 & 15 & - & 3 & - & 4 & 99 & 88 & 136 & 277 & 298 \\
\hline $\mathrm{Rb}$ & 0.9 & 6.1 & 0.5 & 174.8 & 1.3 & 2.1 & 8.3 & 32.5 & 36.4 & 23.5 & 25.3 \\
\hline Cs & 0.6 & 6.1 & 0.1 & 30.7 & 0.4 & 2.2 & 0.9 & 5.2 & 6.4 & 1.7 & 2.0 \\
\hline $\mathrm{Ba}$ & 12 & 83 & - & 11 & 3 & 4 & 56 & 84 & 95 & 95 & 97 \\
\hline $\mathrm{Sr}$ & 2.4 & 3.9 & 0.8 & 1.7 & 2.4 & 1.9 & 113.1 & 127.1 & 139.3 & 476.3 & 495.2 \\
\hline $\mathrm{Ga}$ & 3.0 & 3.5 & 2.3 & 3.4 & 1.9 & 2.4 & 45 & 45.8 & 54.5 & 34.1 & 37.9 \\
\hline V & 46 & 40 & 40 & 49 & 29 & 37 & 15 & 10 & 8 & 30 & $<8$ \\
\hline $\mathrm{Ta}$ & - & 0.1 & - & - & - & 0.4 & 125.9 & 349.2 & 368.8 & 1.1 & 1.2 \\
\hline $\mathrm{Nb}$ & 2.3 & 2.7 & 1.7 & 1.8 & 0.4 & 2.2 & 76.5 & 230.9 & 277.6 & 1.1 & 0.5 \\
\hline Th & 0.2 & $<0.2$ & $<0.2$ & $<0.2$ & $<0.2$ & $<0.2$ & 0.9 & 1.7 & 1.5 & 4.3 & 5.5 \\
\hline $\mathrm{U}$ & 0.4 & 2.5 & 0.5 & 0.7 & 1.2 & 1.0 & 14.7 & 33.9 & 32.5 & 0.6 & 1.3 \\
\hline $\mathrm{Zr}$ & 5.4 & 4.6 & 4.8 & 5.8 & 3.4 & 5.5 & 35.9 & 162.3 & 153.4 & 15.7 & 22.9 \\
\hline $\mathrm{Hf}$ & 0.1 & 0.2 & $<0.1$ & 0.1 & $<0.1$ & $<0.1$ & 3.9 & 12.3 & 15.0 & 1.8 & 2.9 \\
\hline $\mathrm{Y}$ & 2.4 & 7.0 & 1.6 & 2.4 & 0.6 & 3.9 & 1.5 & 3.1 & 3.0 & 0.4 & 0.4 \\
\hline $\mathrm{Sc}$ & 7 & 4 & 6 & 7 & 4 & 6 & - & - & - & - & - \\
\hline $\mathrm{Ni}$ & $2,062.8$ & $2,183.5$ & $2,054.8$ & $2,436.1$ & $2,283.2$ & $2,235.9$ & 0.4 & 1.8 & 2.0 & 5.7 & 5.1 \\
\hline $\mathrm{Cr}$ & $6,101.3$ & $6,176.5$ & $6,046.6$ & $6,484.3$ & $6,539.0$ & $6,101.3$ & - & - & - & - & - \\
\hline $\mathrm{Cu}$ & - & 3.6 & 0.1 & 1.2 & 0.1 & - & 0.3 & 1.7 & 1.4 & 0.7 & 0.5 \\
\hline $\mathrm{Zn}$ & 22 & 16 & 16 & 19 & 13 & 27 & - & 9 & 8 & - & - \\
\hline $\mathrm{Pb}$ & 0.1 & 0.4 & 0.1 & 0.9 & 0.2 & 0.1 & 0.3 & 0.4 & 0.3 & 1.9 & 1.7 \\
\hline $\mathrm{La}(\mathrm{ppm})$ & 1.7 & 0.9 & 1.1 & 0.7 & 0.6 & 0.6 & 1.2 & 2.1 & 2.1 & 4.3 & 4.3 \\
\hline $\mathrm{Ce}$ & 2.2 & 2.6 & 2.1 & 1.4 & 0.9 & 1.6 & 2.2 & 4.1 & 3.7 & 4.6 & 3.6 \\
\hline $\operatorname{Pr}$ & 0.27 & 0.38 & 0.23 & 0.25 & 0.11 & 0.22 & 0.29 & 0.56 & 0.52 & 0.34 & 0.30 \\
\hline $\mathrm{Nd}$ & 1.0 & 1.8 & 0.7 & 1.6 & 0.4 & 1.1 & 0.9 & 1.7 & 1.8 & 1.3 & 1.0 \\
\hline $\mathrm{Sm}$ & 0.32 & 0.55 & 0.25 & 0.34 & 0.11 & 0.28 & 0.34 & 0.66 & 0.50 & 0.17 & 0.13 \\
\hline $\mathrm{Eu}$ & 0.07 & 0.16 & 0.07 & 0.07 & 0.03 & 0.08 & 1.31 & 1.85 & 1.88 & 1.24 & 1.17 \\
\hline Gd & 0.33 & 0.67 & 0.29 & 0.37 & 0.08 & 0.39 & 0.3 & 0.61 & 0.46 & 0.14 & 0.16 \\
\hline $\mathrm{Tb}$ & 0.07 & 0.17 & 0.05 & 0.06 & 0.01 & 0.07 & 0.04 & 0.1 & 0.10 & 0.02 & $<0.01$ \\
\hline Dy & 0.46 & 1.29 & 0.30 & 0.39 & 0.09 & 0.57 & 0.29 & 0.63 & 0.58 & 0.12 & $<0.05$ \\
\hline Ho & 0.08 & 0.27 & 0.08 & 0.09 & 0.02 & 0.14 & 0.06 & 0.13 & 0.12 & $<0.02$ & $<0.02$ \\
\hline $\mathrm{Er}$ & 0.25 & 0.90 & 0.21 & 0.19 & 0.08 & 0.49 & 0.15 & 0.42 & 0.38 & 0.04 & $<0.03$ \\
\hline $\mathrm{Tm}$ & 0.04 & 0.14 & 0.03 & 0.03 & $<0.01$ & 0.06 & 0.02 & 0.07 & 0.06 & $<0.01$ & $<0.01$ \\
\hline $\mathrm{Yb}$ & 0.28 & 0.91 & 0.12 & 0.15 & 0.12 & 0.33 & 0.23 & 0.53 & 0.60 & $<0.05$ & $<0.05$ \\
\hline $\mathrm{Lu}$ & 0.04 & 0.14 & 0.02 & 0.04 & $<0.01$ & 0.07 & 0.04 & 0.09 & 0.08 & $<0.01$ & $<0.01$ \\
\hline $\mathrm{La}_{\mathrm{N}} / \mathrm{Sm}_{\mathrm{N}} v s \mathrm{Sm}_{\mathrm{N}}$ & 5.48 & 2.90 & 3.54 & 2.25 & 1.93 & 1.93 & 3.87 & 6.77 & 6.77 & 13.87 & 13.87 \\
\hline $\mathbf{G d}_{\mathrm{N}} / \mathbf{Y b}_{\mathrm{N}} v s \mathrm{Yb}_{\mathrm{N}}$ & 1.27 & 2.58 & 1.11 & 1.42 & 0.30 & 1.50 & 1.15 & 2.35 & 1.77 & 0.54 & 0.61 \\
\hline $\mathrm{Eu} / \mathrm{Eu}^{*}$ & 0.65 & 0.80 & 0.79 & 0.60 & 0.97 & 0.74 & 12.54 & 8.91 & 11.98 & 24.57 & 24.80 \\
\hline
\end{tabular}


On the chondrite-normalized REE plot (Fig. 4F), the samples from albite granite facies have moderate to high degree of fractionation for LREE $\left(\mathrm{La}_{N} / \mathrm{Sm}_{N}\right.$ vs. $\left.\mathrm{Sm}_{N}=3.87-6.77\right)$, while for samples from albitized facies a high degree of fractionation for $\operatorname{LREE}\left(\mathrm{La}_{\mathrm{N}} / \mathrm{Sm}_{\mathrm{N}} v s . \mathrm{Sm}_{\mathrm{N}}=13.87\right)$ is observed. All samples have low degree of fractionation for $\operatorname{HREE}\left(\mathrm{Gd}_{\mathrm{N}} / \mathrm{Yb}_{\mathrm{N}} v s \mathrm{Yb}_{\mathrm{N}}=\right.$ 0.54-2.35), but with a higher $\Sigma \mathrm{HREE}_{\mathrm{N}}$ content in the albite granite facies. All samples show a strong positive Eu anomaly $\left(\mathrm{Eu} / \mathrm{Eu}^{*}=2.45-2.47\right)$, attributed to high plagioclase content.

\section{GEOCHRONOLOGY}

${ }^{207} \mathrm{U}-{ }^{235} \mathrm{~Pb}$ and ${ }^{40} \mathrm{Ar} /{ }^{39} \mathrm{Ar}$ isotopic geology data have been widely applied to determine the absolute time from magmatic crystallization to cooling hydrothermal events of the ore deposits formation (e.g., Deckart et al. 2005, Chiaradia et al. 2013). In this topic, we present the ${ }^{207} \mathrm{U}-{ }^{235} \mathrm{~Pb}$ and ${ }^{40} \mathrm{Ar} /{ }^{39} \mathrm{Ar}$ data of $\mathrm{Be}$-rich albite granite and phlogopite hornfels, respectively.
${ }^{207} \mathrm{U}^{235} \mathrm{~Pb}$ data were acquired from the two zircon populations (Tab. 2), composed by pale-pink to pale-brown euhedral to subhedral short-prismatic crystals, showing oscillatory internal zoning, with size from 130 to $370 \mu \mathrm{m}$ and rare micro-inclusions or micro-fractures. The first zircon population (type 1) is dominant, with 33 grains analyzed, showing ratio of $\mathrm{Th} / \mathrm{U}=0.22-0.54$ and defining two mean weighted ages of $3513 \pm 10 \mathrm{Ma}$ and $3430 \pm 14 \mathrm{Ma}$ (Fig. 5A), interpreted as inheritance ages from Archean regional units. In contrast, eight grains were analyzed in the second zircon population (type 2), whose ratio of $\mathrm{Th} / \mathrm{U}=0.24-0.37$, defining two mean weighted ages of $580 \pm 5 \mathrm{Ma}$ and $561 \pm 4 \mathrm{Ma}$ (Fig. 5B). The oldest age is also interpreted as inheritance, but linked to others Neoproterozoic regional units, while the second value is interpreted as the crystallization age for Be-rich albite granite.

${ }^{40} \mathrm{Ar} /{ }^{39} \mathrm{Ar}$ data were obtained on pure phlogopite crystals handpicked from emerald-phlogopite hornfels (Tab. 3). The incremental-heating spectra revealed for $\mathrm{Ca} / \mathrm{K}$ and $\mathrm{Cl} / \mathrm{K}$

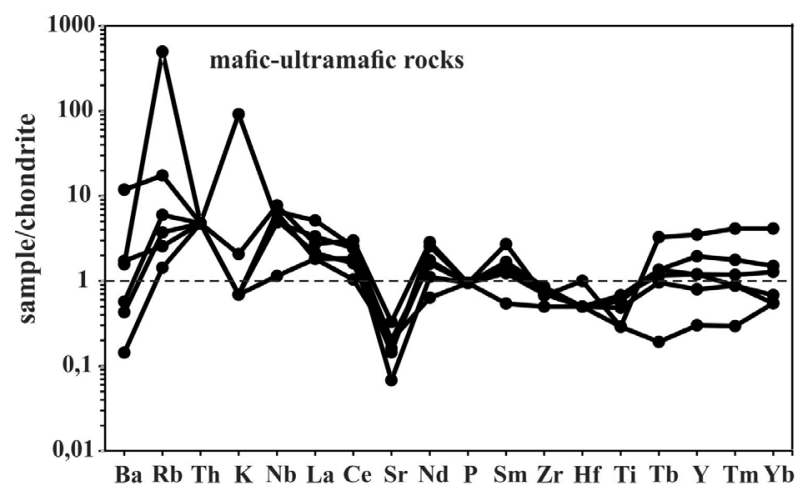

C
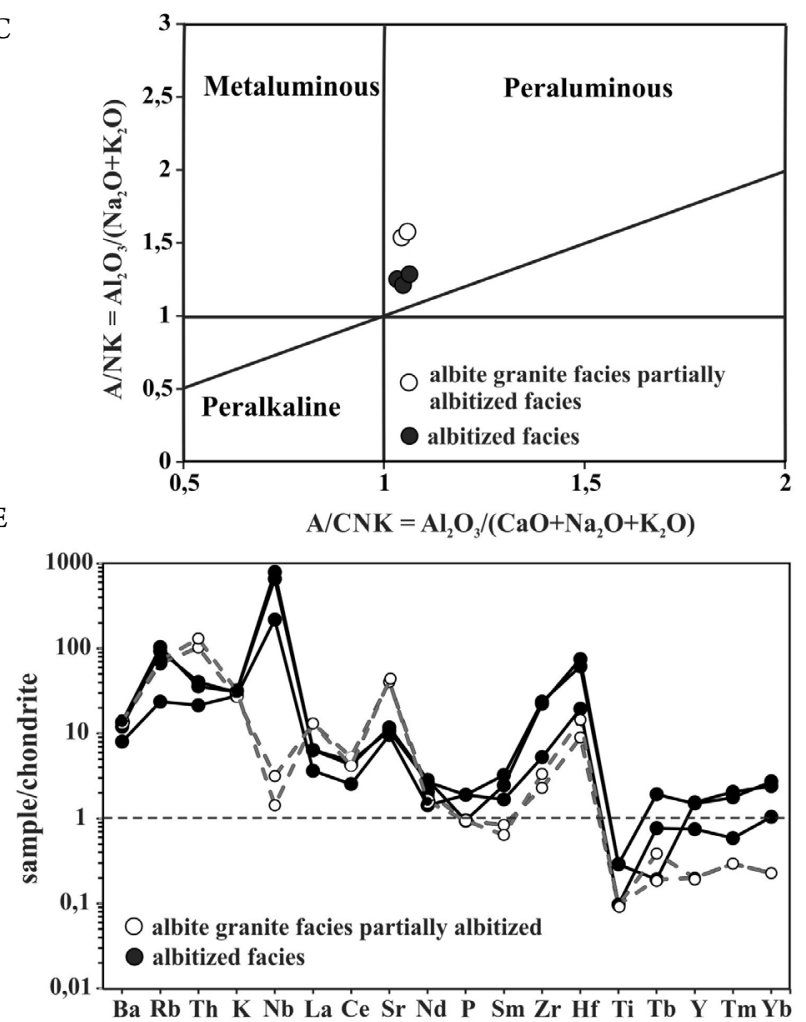

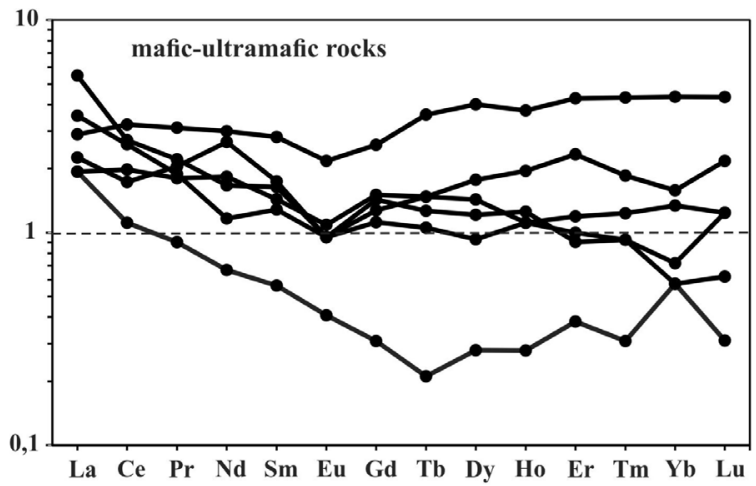

$\mathrm{D}$
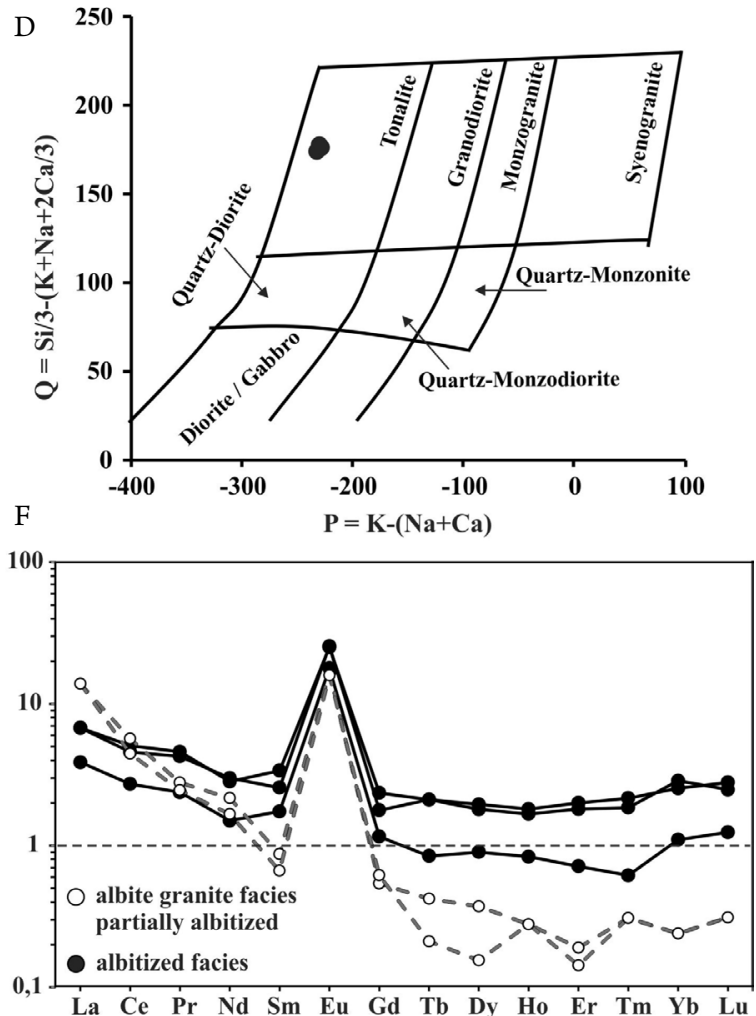

Figure 4. (A and B) Multi-elements and rare earth elements (REE) distribution patterns in mafic-ultramafic rocks; (C) Aluminum saturation index (ASI total) diagram applied to samples from Be-rich albite granite (Maniar \& Piccoli 1989); (D) Chemical classification of igneous pegmatites (Debon \& Le Fort 1983) applied to Be-rich albite granite; (E and F) Multi-elements and REE distribution patterns in samples from Be-rich albite granite. All values are normalized according to Thompson (1982) primordial mantle and Boynton (1984) chondrite. 
ratios variations measurements indicate thermal imbalance (loss of ${ }^{39} \mathrm{Ar}$ ) for different K-bearing phases with the same ${ }^{40} \mathrm{Ar}-{ }^{39} \mathrm{Ar}$ age, mainly during the first-stages under low temperature condition (Fig. 6A). This record may be associated to crystallography oscillation in K-bearing mineral (phlogopite), from edge to core parts in non-retentive sites, favoring to loss of ${ }^{39} \mathrm{Ar}$ by recoil (Harrison et al. 2009, Cosca et al. 2011, Verdel et al. 2012). Despite this initial loss of ${ }^{39} \mathrm{Ar}$, the analytical data is homogeneous, exhibiting stable plateau age at the highest temperatures, ranging from $542 \pm 7$ to $554 \pm 5 \mathrm{Ma}$ and they are interpreted as cooling or closure interval-time for metasomatic event responsible by Fazenda Bonfim emerald deposit formation. In this context, a consistent and perfect plateau at the age of $553 \pm 4 \mathrm{Ma}$ can be identified, calculated with $93.5 \%$ of the total ${ }^{39} \mathrm{Ar}$ released, with MSWD $=0.207$ and analytical error around 3.84\%(Fig. 6B).

\section{DISCUSSION}

The Fazenda Bonfim is a classic example of emerald deposit formed through metasomatic interactions between Be-rich granite intrusions and $\mathrm{Cr}( \pm \mathrm{V})$-rich mafic-ultramafic rocks, referred by some authors as "igneous model" (e.g., Grundmann \& Morteani 1989, Laurs et al. 1996, Schwarz \& Giuliani 2001, Groat et al. 2002, Vapnik et al. 2006), or as tectonic-magmatic-related model (Giuliani et al. 2019). This metasomatic process involves reaction and permeability of a fluid advancing through lithological contacts, configuring a reaction front within the host rocks. Lithological contrast, temperature and pressure are factors that control the intensity of metasomatism.

The hydration of ferromagnesian silicate minerals from mafic-ultramafic rocks is common, leading to the serpentinization and talcification reactions under low/medium temperature at the prograde regional metamorphism conditions (Alt \& Shanks 2003, Zhang et al. 2011). In the Fazenda Bonfim emerald deposit, the mafic-ultramafic rocks have different degrees of metasomatic transformation (serpentinization/ talcification), marked by variable proportions of serpentine and talc, associated with tremolite, actinolite, biotite and phlogopite, configuring partial to total substitution of the primary ferromagnesian silicate minerals, indicated by the presence of olivine and pyroxene ghost or relics/skeletal phenocrysts.

Table 2. U-Pb isotopic data for zircon crystals from the Be-rich albite granite.

\begin{tabular}{|c|c|c|c|c|c|c|c|c|c|c|c|c|c|c|c|c|c|}
\hline $\begin{array}{l}\text { Zircon } \\
\text { crystals }\end{array}$ & ${ }^{204} \mathbf{P b}$ & ${ }^{206} \mathbf{P b}$ & $\mathbf{T h} / \mathbf{U}$ & $\begin{array}{c}\text { Isotope } \\
\text { ratio } \\
{ }^{206} \mathbf{P b} /{ }^{204} \mathbf{P b} \\
\end{array}$ & $1 \sigma \%$ & $\begin{array}{c}\text { Isotope } \\
\text { ratio } \\
{ }^{207} \mathbf{P b} /{ }^{235} \mathbf{U} \\
\end{array}$ & $\begin{array}{c}1 \sigma \\
(\%)\end{array}$ & $\begin{array}{c}\text { Isotope } \\
\text { ratio } \\
{ }^{206} \mathbf{P b} /{ }^{238} \mathbf{U}\end{array}$ & $\begin{array}{l}1 \sigma \\
(\%)\end{array}$ & Rho & $\begin{array}{c}\text { Age (Ma) } \\
{ }^{207} \mathbf{P b} /{ }^{206} \mathbf{P b}\end{array}$ & $\begin{array}{c}2 \sigma \\
(\text { abs })\end{array}$ & $\begin{array}{c}\text { Age (Ma) } \\
{ }^{206} \mathrm{~Pb} /{ }^{238} \mathrm{U}\end{array}$ & $\begin{array}{c}2 \sigma \\
(\mathrm{abs})\end{array}$ & $\begin{array}{c}\text { Age (Ma) } \\
{ }^{207} \mathbf{P b} /{ }^{235} \mathbf{U}\end{array}$ & $\begin{array}{c}2 \sigma \\
(\text { abs })\end{array}$ & $\begin{array}{c}\% \\
\text { U-Pb } \\
\text { disc }\end{array}$ \\
\hline 020-A3-Zir10N & 7 & 0.0026 & 0.410 & 100,561 & 21.56 & 30.818 & 1.60 & 0.7200 & 1.14 & 0.71 & 3,523 & 33 & 3,496 & 61 & 3,513 & 31 & 0.76 \\
\hline 036-A1-Zir26 & 9 & 0.0045 & 0.310 & 166,129 & 13.56 & 29.989 & 0.91 & 0.6971 & 0.65 & 0.71 & 3,531 & 16 & 3,410 & 34 & 3,486 & 18 & 3.44 \\
\hline 004-A1-Zir1 & 20 & 0.0107 & 0.504 & 360,456 & 36.17 & 29.782 & 0.86 & 0.7008 & 0.58 & 0.68 & 3,512 & 16 & 3,424 & 31 & 3,480 & 17 & 2.51 \\
\hline 016-A3-Zir8N & 10 & 0.0031 & 0.382 & 143,725 & 21.13 & 29.652 & 1.15 & 0.6908 & 0.91 & 0.79 & 3,527 & 18 & 3,386 & 48 & 3,475 & 23 & 4.01 \\
\hline 029-A1-Zir21 & 12 & 0.0100 & 0.402 & 313,154 & 16.39 & 29.572 & 1.15 & 0.6965 & 0.65 & 0.57 & 3,511 & 27 & 3,407 & 34 & 3,473 & 22 & 2.94 \\
\hline 037-A1-Zir27 & 14 & 0.0083 & 0.444 & 237,820 & 17.12 & 29.364 & 0.84 & 0.6853 & 0.60 & 0.71 & 3,525 & 14 & 3,365 & 31 & 3,466 & 16 & 4.54 \\
\hline 025-A3-Zir12 & 12 & 0.0035 & 0.475 & 180,516 & 43.58 & 29.305 & 2.56 & 0.6829 & 1.64 & 0.64 & 3,527 & 59 & 3,355 & 85 & 3,464 & 50 & 4.87 \\
\hline 056-A3-Zir30 & 19 & 0.0076 & 0.546 & 199,978 & 18.77 & 29.240 & 0.82 & 0.6849 & 0.64 & 0.79 & 3,519 & 11 & 3,363 & 34 & 3,462 & 16 & 4.43 \\
\hline 037-A3-Zir20N & 24 & 0.0143 & 0.374 & 213,424 & 25.23 & 29.112 & 0.71 & 0.6786 & 0.52 & 0.73 & 3,527 & 9 & 3,339 & 27 & 3,457 & 14 & 5.32 \\
\hline 065-A3-Zir36 & 20 & 0.0069 & 0.412 & 179,906 & 22.77 & 29.037 & 0.80 & 0.6748 & 0.59 & 0.74 & 3,531 & 12 & 3,324 & 31 & 3,455 & 16 & 5.86 \\
\hline 027-A1-Zir19 & 6 & 0.0040 & 0.409 & 219,971 & 14.68 & 28.791 & 0.95 & 0.6694 & 0.68 & 0.72 & 3,531 & 17 & 3,303 & 35 & 3,446 & 18 & 6.43 \\
\hline 043-A3-Zir23 & 42 & 0.0038 & 0.307 & 46,818 & 32.44 & 28.698 & 1.19 & 0.6750 & 0.90 & 0.76 & 3,513 & 21 & 3,325 & 47 & 3,443 & 23 & 5.34 \\
\hline 036-A3-Zir19 & 42 & 0.0129 & 0.450 & 96,753 & 42.53 & 28.372 & 1.47 & 0.6771 & 1.36 & 0.93 & 3,490 & 13 & 3,333 & 71 & 3,432 & 29 & 4.49 \\
\hline 059-A3-Zir33N & 31 & 0.0046 & 0.520 & 45,602 & 32.32 & 28.316 & 0.98 & 0.6733 & 0.71 & 0.72 & 3,496 & 17 & 3,319 & 37 & 3,430 & 19 & 5.06 \\
\hline 026-A1-Zir18 & 5 & 0.0123 & 0.440 & $2,170,464$ & 76.17 & 28.295 & 0.91 & 0.6731 & 0.58 & 0.63 & 3,495 & 18 & 3,318 & 30 & 3,429 & 18 & 5.07 \\
\hline 006-A2-Zir3 & 3 & 0.0152 & 0.508 & 814,500 & 6.55 & 28.141 & 0.89 & 0.6692 & 0.56 & 0.63 & 3,496 & 18 & 3,303 & 29 & 3,424 & 17 & 5.51 \\
\hline 045-A2-Zir27 & 1 & 0.0051 & 0.633 & 316,236 & 5.97 & 28.046 & 1.33 & 0.6681 & 1.05 & 0.79 & 3,493 & 22 & 3,299 & 54 & 3,421 & 26 & 5.56 \\
\hline 018-A3-Zir9N & 10 & 0.0035 & 0.333 & 128,762 & 14.29 & 27.994 & 1.32 & 0.6668 & 0.96 & 0.73 & 3,493 & 25 & 3,294 & 50 & 3,419 & 26 & 5.71 \\
\hline 022-A2-Zir13 & 1 & 0.0037 & 0.361 & 230,609 & 1.53 & 27.951 & 0.98 & 0.6573 & 0.71 & 0.73 & 3,513 & 17 & 3,257 & 36 & 3,417 & 19 & 7.30 \\
\hline 013-A3-Zir5 & 18 & 0.0023 & 0.285 & 63,672 & 19.13 & 27.934 & 1.34 & 0.6641 & 1.05 & 0.79 & 3,496 & 23 & 3,283 & 54 & 3,417 & 26 & 6.10 \\
\hline 033-A3-Zir17N & 29 & 0.0153 & 0.426 & 284,623 & 25.56 & 27.891 & 1.07 & 0.6504 & 0.94 & 0.88 & 3,526 & 11 & 3,230 & 48 & 3,415 & 21 & 8.40 \\
\hline 004-A2-Zir1 & 4 & 0.0082 & 0.359 & 445,989 & 9.52 & 27.665 & 0.97 & 0.6633 & 0.56 & 0.58 & 3,483 & 22 & 3,280 & 29 & 3,407 & 19 & 5.82 \\
\hline 040-A2-Zir24 & 1 & 0.0058 & 0.227 & 375,488 & 7.03 & 27.527 & 1.11 & 0.6677 & 0.72 & 0.65 & 3,465 & 24 & 3,297 & 37 & 3,402 & 22 & 4.84 \\
\hline 019-A3-Zir9B & 9 & 0.0022 & 0.286 & 87,778 & 13.14 & 26.936 & 1.62 & 0.6501 & 1.35 & 0.83 & 3,473 & 25 & 3,229 & 69 & 3,381 & 32 & 7.03 \\
\hline 017-A2-Zir10 & 2 & 0.0133 & 0.454 & $1,591,780$ & 50.82 & 26.868 & 0.83 & 0.6509 & 0.58 & 0.70 & 3,467 & 14 & 3,232 & 29 & 3,379 & 16 & 6.78 \\
\hline 034-A1-Zir24 & 11 & 0.0061 & 0.567 & 210,563 & 14.70 & 26.775 & 1.34 & 0.6426 & 1.07 & 0.80 & 3,481 & 22 & 3,199 & 54 & 3,375 & 26 & 8.10 \\
\hline 043-A1-Zir31 & 17 & 0.0110 & 0.282 & 300,543 & 17.76 & 26.717 & 0.84 & 0.6447 & 0.63 & 0.75 & 3,473 & 13 & 3,208 & 32 & 3,373 & 16 & 7.64 \\
\hline 015-A3-Zir7 & 12 & 0.0039 & 0.371 & 127,190 & 14.78 & 26.706 & 1.02 & 0.6504 & 0.74 & 0.73 & 3,459 & 18 & 3,230 & 38 & 3,373 & 20 & 6.62 \\
\hline 040-A3-Zir22 & 17 & 0.0033 & 0.265 & 88,422 & 17.59 & 26.615 & 1.06 & 0.6481 & 0.78 & 0.74 & 3,459 & 19 & 3,221 & 40 & 3,369 & 21 & 6.89 \\
\hline 029-A2-Zir17 & 12 & 0.0114 & 0.407 & 564,707 & 17.52 & 26.257 & 1.09 & 0.6405 & 0.63 & 0.58 & 3,456 & 25 & 3,191 & 32 & 3,356 & 21 & 7.68 \\
\hline 028-A2-Zir16 & 1 & 0.0237 & 0.568 & $1,448,801$ & 3.99 & 26.217 & 0.89 & 0.6477 & 0.62 & 0.70 & 3,437 & 16 & 3,219 & 31 & 3,355 & 17 & 6.33 \\
\hline 010-A2-Zir5 & 2 & 0.0066 & 0.326 & 389,038 & 8.35 & 26.112 & 0.90 & 0.6297 & 0.56 & 0.62 & 3,474 & 18 & 3,148 & 28 & 3,351 & 17 & 9.38 \\
\hline 039-A1-Zir29 & 10 & 0.0071 & 0.311 & 255,118 & 14.51 & 30.021 & 0.96 & 0.7118 & 0.68 & 0.71 & 3,500 & 18 & 3,465 & 36 & 3,487 & 19 & 1.00 \\
\hline 041-A2-Zir25 & 1 & 0.0027 & 0.326 & 166,806 & 3.03 & 0.785 & 1.09 & 0.0942 & 0.72 & 0.66 & 620 & 32 & 580 & 8 & 589 & 10 & 6.39 \\
\hline 019-A1-Zir14 & 16 & 0.0027 & 0.289 & 69,275 & 20.19 & 0.774 & 1.23 & 0.0936 & 0.77 & 0.63 & 603 & 38 & 577 & 9 & 582 & 11 & 4.34 \\
\hline 068-A3-Zir38B & 20 & 0.0007 & 0.308 & 16,591 & 22.23 & 0.772 & 2.55 & 0.0932 & 1.74 & 0.68 & 606 & 78 & 575 & 19 & 581 & 22 & 5.11 \\
\hline 046-A3-Zir25C & 17 & 0.0040 & 0.243 & 102,751 & 18.90 & 0.771 & 1.00 & 0.0939 & 0.77 & 0.77 & 587 & 23 & 579 & 9 & 580 & 9 & 1.43 \\
\hline 048-A3-Zir26 & 16 & 0.0031 & 0.251 & 69,740 & 21.53 & 0.748 & 1.11 & 0.0915 & 0.72 & 0.65 & 579 & 33 & 564 & 8 & 567 & 10 & 2.56 \\
\hline 005-A2-Zir2 & 4 & 0.0047 & 0.258 & 248,888 & 8.17 & 0.745 & 0.90 & 0.0904 & 0.59 & 0.66 & 597 & 25 & 558 & 6 & 566 & 8 & 6.61 \\
\hline 023-A2-Zir14 & 2 & 0.0027 & 0.379 & 162,669 & 4.13 & 0.745 & 1.09 & 0.0904 & 0.69 & 0.63 & 594 & 33 & 558 & 7 & 565 & 9 & 6.13 \\
\hline 058-A3-Zir32 & 23 & 0.0022 & 0.308 & 138,618 & 74.90 & 0.742 & 1.11 & 0.0908 & 0.79 & 0.71 & 575 & 30 & 561 & 8 & 563 & 10 & 2.58 \\
\hline
\end{tabular}


A
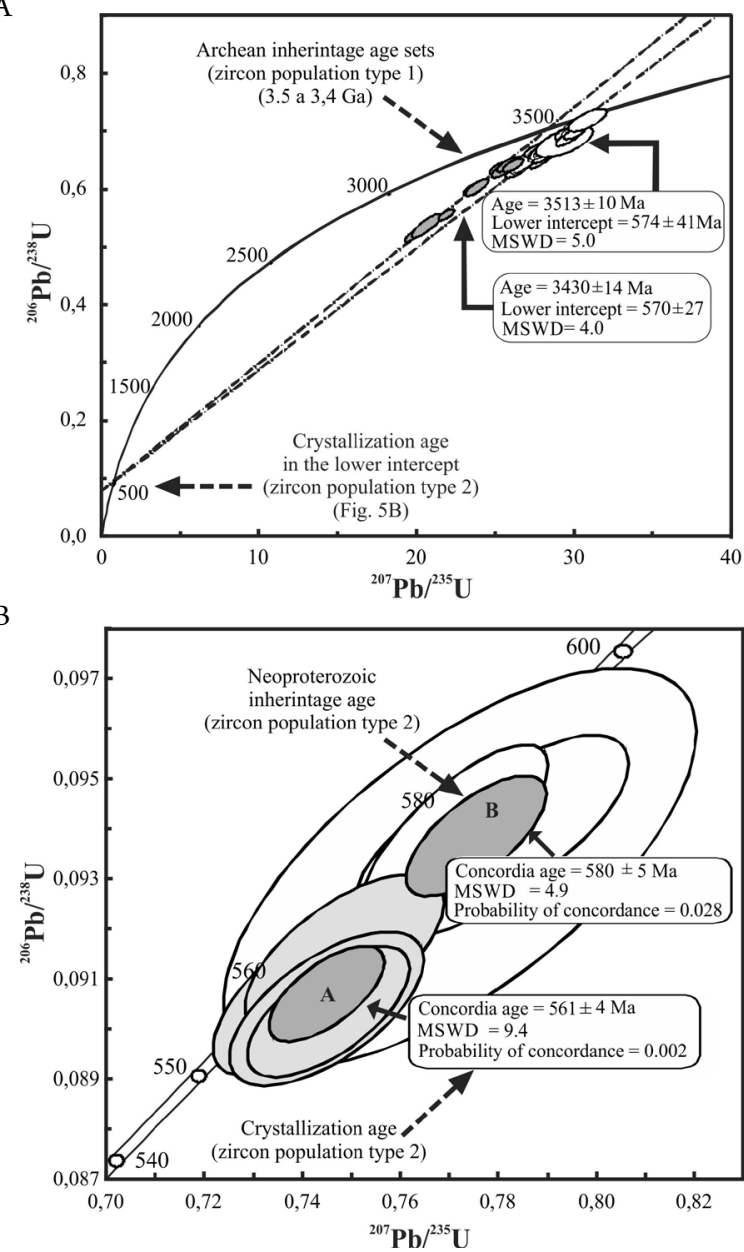

Figure 5. (A) U-Pb discordia diagram for all zircon populations (type 1 and type 2) identified in the F04-JM01 sample from the Be-rich albite granite; (B) U-Pb concordia diagram for second zircon population (type 2), indicating the crystallization age for the Be-rich albite granite.
Although the primary features (texture, mineralogy and chemistry) from possible protoliths are obliterated, the high $\mathrm{Mg}, \mathrm{Ni}$ and $\mathrm{Cr}( \pm \mathrm{V})$ contents, associated to chromite presence, point to the dominant ultramafic nature for these rocks.

Be-rich albite granite, which is partially to totally albitized, represents a highly fractioned and fluid-supersaturated melt, geochemically fertile rare-metal (enriched with $\mathrm{Nb}, \mathrm{Ta}, \pm$ $\mathrm{U})$. Although some trace elements, such as $\mathrm{Y}, \mathrm{Zr}, \mathrm{U}, \mathrm{Nb}$, and Ta, can be mobilized during extreme metasomatic overprint

A

$\mathrm{B}$

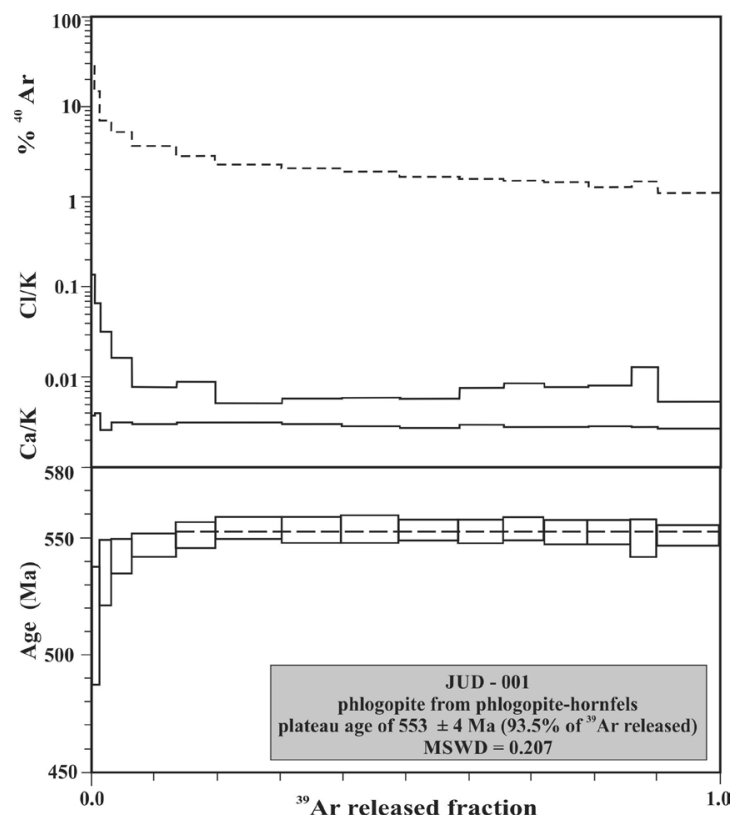

Figure 6. (A) $\%{ }^{40} \mathrm{Ar}, \mathrm{Ca} / \mathrm{K}$ and $\mathrm{Cl} / \mathrm{K}$ ratio measurements; (B) ${ }^{40} \mathrm{Ar}^{-39} \mathrm{Ar}$ age spectra for phlogopite crystals from the phlogopite hornfels (blackwall zone). Plateau age calculated (553 $\pm 4 \mathrm{Ma})$ and marked with dotted line.

Table 3. ${ }^{40} \mathrm{Ar}-{ }^{39} \mathrm{Ar}$ data for phlogopite from the phlogopite hornfels or "blackwall" zone (D-713: JUD-001 sample).

\begin{tabular}{lcccccccc}
\hline Power & ${ }^{36} \mathbf{A r} /{ }^{40} \mathbf{A r}$ & ${ }^{39} \mathbf{A r} /{ }^{40} \mathbf{A r}$ & $\mathbf{r}$ & $\mathbf{C a} / \mathbf{K}$ & $\mathbf{\%}^{\mathbf{4 0}} \mathbf{A t m}$ & $\mathbf{\%}^{39} \mathbf{A r}$ & ${ }^{40} \mathbf{A r}{ }^{*}{ }^{39} \mathbf{K}$ & Age \\
\hline 3.00 & 0.002806 & 0.017558 & 0.007 & 0.216 & 82.86 & 0.25 & $9.7 \pm 6.6$ & $136.9 \pm 88.9$ \\
4.00 & 0.001047 & 0.020021 & 0.003 & 0.137 & 30.91 & 0.40 & $34.5 \pm 4.1$ & $441.9 \pm 47.1$ \\
4.60 & 0.000503 & 0.020860 & 0.002 & 0.067 & 14.83 & 0.82 & $40.8 \pm 2.3$ & $512.4 \pm 25.4$ \\
5.00 & 0.000235 & 0.021680 & 0.001 & 0.032 & 6.93 & 1.71 & $42.9 \pm 1.3$ & $535.2 \pm 13.9$ \\
5.50 & 0.000176 & 0.021749 & 0.001 & 0.016 & 5.18 & 3.34 & $43.6 \pm 0.7$ & $542.4 \pm 7.4$ \\
6.00 & 0.000124 & 0.021885 & 0.001 & 0.008 & 3.67 & 7.00 & $44.0 \pm 0.5$ & $547 \pm 5.1$ \\
6.50 & 0.000096 & 0.021966 & 0.001 & 0.009 & 2.82 & 6.19 & $11.2 \pm 0.5$ & $549.3 \pm 5.8$ \\
7.00 & 0.000077 & 0.021855 & 0.001 & 0.005 & 2.27 & 10.58 & $44.7 \pm 0.4$ & $554.5 \pm 4.7$ \\
7.50 & 0.000070 & 0.021954 & 0.000 & 0.006 & 2.07 & 9.40 & $44.6 \pm 0.5$ & $553.3 \pm 5.6$ \\
8.00 & 0.000064 & 0.021965 & 0.001 & 0.006 & 1.89 & 9.23 & $44.7 \pm 0.6$ & $533.9 \pm 6$ \\
8.50 & 0.000056 & 0.022027 & 0.000 & 0.006 & 1.66 & 9.54 & $44.6 \pm 0.4$ & $553.7 \pm 4.3$ \\
9.00 & 0.000053 & 0.022086 & 0.000 & 0.008 & 1.57 & 7.09 & $44.6 \pm 0.5$ & $552.8 \pm 4.9$ \\
10.00 & 0.000051 & 0.022048 & 0.000 & 0.009 & 1.51 & 6.37 & $44.7 \pm 0.5$ & $554 \pm 5.1$ \\
11.000 & 0.000050 & 0.022117 & 0.000 & 0.008 & 1.46 & 6.97 & $44.6 \pm 0.5$ & $552.7 \pm 5.4$ \\
12.50 & 0.000044 & 0.022152 & 0.000 & 0.008 & 1.28 & 6.80 & $44.6 \pm 0.5$ & $552.8 \pm 5.5$ \\
14.00 & 0.000050 & 0.022236 & 0.000 & 0.013 & 1.48 & 4.18 & $44.3 \pm 0.7$ & $550.1 \pm 8$ \\
25.00 & 0.000037 & 0.022279 & 0.000 & 0.005 & 1.10 & 10.13 & $44.4 \pm 0.4$ & $551 \pm 4.5$ \\
\hline
\end{tabular}


(Salvi et al. 2000, Jiang et al. 2005, Sheard et al. 2012). On the other hand, U-rich albitized rocks from northeastern Brazil have also been reported over time (e.g., Lobato \& Fyfe 1990, Silveira et al. 1991). In general, this magmatism was emplaced under strike-slip regime at the end of Brasiliano orogeny. Regional mega-shear zones or trans-crust faults played an important role in the conduction and accommodation of this granitic melts toward upper crustal levels, controlled by successive reactivations over time with associated magmatic pulses (Vauchez et al. 1995, Jardim de Sá et al. 1981, Brito Neves 2000, Araújo et al. 2001, Santos et al. 2008).

Fractionated granitic melts (e.g., microcline-albite granite and albite granite) emplaced in the upper crust, may be totally to partially albitized subsequently through metasomatic front leading an overall change in mineralogical (i.e., oligoclase and microcline are replaced by albite) and chemical composition (Haapala 1997, Engvik et al.2008, Kaur et al. 2012). Normally, albitization leads to hydration, major gain in $\mathrm{Na}$, minor gain in $\mathrm{Si}$ and losses of $\mathrm{Ca}, \mathrm{K}, \mathrm{Fe}, \mathrm{Mg}, \mathrm{P}, \mathrm{Ti}, \mathrm{Rb}, \mathrm{Sr}$, $\mathrm{Ba}$, and REE (Kaur et al. 2012). LREE fractionation may be intensified due to their significant dependency on the nature of the metasomatic solution, as well as the associated mineral phases and the presence of specific ligands at elevated temperatures (Carcangiu et al. 1997).

According to Santiago et al. (2018), there are polystages of emerald growths simultaneous to the deformation at the Fazenda Bonfim deposit. Therefore, it is reasonable to say that the structural control and the lithological-contrast had an important role in the fluid flow and the ore-shoot geometry (nucleation and growth of emerald crystals). In this place, fluid circulation was more likely to be focused in the intra-plane $S$-foliation, in order for the best-mineralized site to occur at the contact zone (blackwall) between albite granite $v s$. mafic-ultramafic rocks. At this site, the fluid systems were important in cation transference, with the addition of $\mathrm{K}, \mathrm{H}, \mathrm{Li}, \mathrm{Cs}, \mathrm{Rb}, \mathrm{Be}$,
$\mathrm{Al}$, and $\mathrm{Na}$, and the removal of $\mathrm{Si}, \mathrm{Mg}, \mathrm{Ca}, \mathrm{Fe}, \mathrm{Cr}, \mathrm{V}$, and $\mathrm{Sc}$. Emerald nucleation and growth in phlogopite schist ("hornfels") was the result of the introduction of $\mathrm{Be}, \mathrm{Al}$, and Na mobilized from albite granite, while $\mathrm{Cr}, \mathrm{Mg}$, $\mathrm{Fe}$, and $\mathrm{V}$ (responsible for emerald coloration) were released from mafic-ultramafic rocks (e.g., Laurs et al. 1996, Groat et al. 2008, Andrianjakavah et al. 2009). According to Santiago et al. (2018), these metasomatic reactions occurred under burial depths from 2 to $5 \mathrm{~km}$ ( $\mathrm{T}=375-430^{\circ} \mathrm{C}$ and $\mathrm{P}=200-600$ bars), corresponding to greenschist to low-amphibolite facies. Reasonable conditions for alkaline-granitoids/pegmatites accommodation during late stages of the Brasiliano Orogeny (Silva et al. 1995, Araújo et al. 2001, Santos et al. 2008, Beurlen et al. 2001,2014), as well as for the albitization process to occur (Petersson \& Eliasson 1997, Kaur et al. 2012).

${ }^{207} \mathrm{U}-{ }^{235} \mathrm{~Pb}$ data revealed that the Be-rich albite granite evolved/fractioned mainly from the Archean crustal rocks melts, marked by inheritance ages between 3,513 \pm 10 and $3,430 \pm 14 \mathrm{Ma}$, probably linked to rocks from the regional unit São José do Campestre Massif (Dantas et al. 2004, 2013). However, presence of Archean rocks with ages around 3.5 Ga in the Bonfim W, Mo, Bi, Au deposit area (see Fig. 1B) has also been reported (Dantas et al. 2014). On the other hand, a small portion from the Neoproterozoic crustal rocks melts (age around $580 \pm 5 \mathrm{Ma}$ ) was also incorporated into this magmatic evolution. Finally, $561 \pm 4$ Ma represents the oldest crystallization age recorded for fertile granitic pegmatite within the Seridó Belt domain, emplaced into the basement rocks and associated with the end of the Brasiliano orogeny, during the Ediacaran Period. (Tab. 4). In addition, ${ }^{40} \mathrm{Ar} /{ }^{39} \mathrm{Ar}$ data $(553 \pm 4 \mathrm{Ma})$ mark the cooling or closure time for the metasomatic event responsible for Fazenda Bonfim emerald deposit formation. The small age difference between $\mathrm{U}-\mathrm{Pb}$ and Ar-Ar data is indicative for a short metasomatic history or for a small cooling interval-time.

Table 4. Synopsis of geochronological Borborema pegmatites available (modified from Beurlen et al. 2014).

\begin{tabular}{|c|c|c|c|c|}
\hline Locality & Method & Mineral & Age (Ma) & Reference \\
\hline Capoeira & $\mathrm{U} / \mathrm{Pb}$ & columbite-tantalite & $509 \pm 3$ & Baumgartner et al. (2006) \\
\hline Mamões & $\mathrm{U} / \mathrm{Pb}$ & columbite-tantalite & $514 \pm 1.2$ & Baumgartner et al. (2006) \\
\hline Malhada Vermelha & $\mathrm{U} / \mathrm{Pb}$ & columbite-tantalite & $511 \pm 0.4$ & Baumgartner et al. (2006) \\
\hline Combi & $\mathrm{U} / \mathrm{Pb}$ & columbite-tantalite & $514 \pm 1.5$ & Baumgartner et al. (2006) \\
\hline Carnaubinha & $\mathrm{U} / \mathrm{Pb}$ & columbite-tantalite & $515 \pm 1$ & Baumgartner et al. (2006) \\
\hline Trigueiro & $\mathrm{U} / \mathrm{Pb}$ & columbite-tantalite & $511 \pm 3$ & Baumgartner et al. (2006) \\
\hline Parelhas & $\mathrm{Ar} / \mathrm{Ar}$ & biotite & $523 \pm 1$ & Araújo et al. (2005) \\
\hline Several & $\mathrm{Rb} / \mathrm{Sr}$ & white-mica & $483-514$ & Almeida et al. $(1968)^{*}$ \\
\hline Several & $\mathrm{Rb} / \mathrm{Sr}$ & k-feldspar & 540 & Almeida et al. $(1968)^{*}$ \\
\hline Several & $\mathrm{K} / \mathrm{Ar}$ & white-mica & $450-520$ & Almeida et al. $(1968)^{*}$ \\
\hline Boqueirão & $\mathrm{Rb} / \mathrm{Sr}$ & lepidolite & $450-462$ & Dirac \& Ebert $(1967)^{*}$ \\
\hline Seridozinho & $\mathrm{K} / \mathrm{Ar}$ & muscovite & $475-512$ & Dirac \& Ebert $(1967)^{*}$ \\
\hline Several & $\mathrm{U} / \mathrm{Pb}$ & uraninite & $460-510$ & Ebert $(1970)^{*}$ \\
\hline Fazenda Bonfim & $\begin{array}{l}\mathrm{Ar} / \mathrm{Ar} \\
\mathrm{U} / \mathrm{Pb}\end{array}$ & $\begin{array}{l}\text { phlogopite } \\
\text { zircon }\end{array}$ & $\begin{array}{l}553 \pm 4 \\
561 \pm 4\end{array}$ & In this paper \\
\hline Several & $\mathrm{U} / \mathrm{Pb}$ & zircon & $555-580$ & Jardim de Sá $(1994)^{*}$ \\
\hline
\end{tabular}

*in Beurlen et al. (2014). 
The Neoproterozoic $\mathrm{Nb}-\mathrm{Ta}( \pm \mathrm{Be}-\mathrm{Li}-\mathrm{Sn})$ granitic pegmatite bodies from the Seridó Belt are linked to the LCT granitic-pegmatite family, subdivided as homogeneous or heterogeneous types. The homogenous type has mineralogy and internal zoning simplified, and shows low potential for $\mathrm{Nb}-\mathrm{Ta}( \pm \mathrm{Be}-\mathrm{Li}-\mathrm{Sn})$ mineralization, while the heterogeneous type has mineralogy and internal zoning diversified, and frequently host $\mathrm{Nb}-\mathrm{Ta}$ ( \pm Be-Li-Sn) mineralization (Silva et al. 1995, Beurlen et al. 2014). The Be-rich albite granite from the Fazenda Bonfim emerald deposit can be classified as homogeneous, linked to granites from the G3 phase (Jardim de Sá et al. 1981), intruded mostly along lithological and structural discontinuities, such as foliation surfaces (Araújo et al. 2001). Probably associated to second tectonic event recognized in the Seridó Belt, which is characterized by thrusting and crustal thickening, with subsequent lateral escape (transcurrent shearing), under greenschist-amphibolite metamorphic facies conditions (Jardim de Sá 1994, Hackspacher et al. 1997).

\section{CONCLUDING REMARKS}

The data presented here, combined with data available from specialized literature, reveal that the Fazenda Bonfim emerald deposit represents a classical metasomatic deposit (i.e., igneous model or type-I, according to Schwarz \& Giuliani 2001, correlate to tectonic-magmatic-related model or type IA, according to Giuliani et al. 2019), formed along lithological contacts between Be-rich albite granite intrusions and $\mathrm{Cr}$ $( \pm \mathrm{V})$-rich mafic-ultramafic host rocks.

This geological framework was built under strong strikeslip dynamics, associated with hydrothermal process, favoring to deformation, serpentinization and talcification of the mafic-ultramafic host rocks. On the other hand, intra-foliation dilating sites favor Be-rich albite granite sin-tectonic emplaced, generating pods and pinch-and-swell structures. The structural control and lithological-contrast were fundamental to the fluid flow and the best ore-shoot geometry, development in the S-foliation intra-plane at the contact zone or "blackwall" zone (phlogopite hornfels). Subsequently, the albitization process, linked to the final-stage of magmatic crystallization, led to an overall change in mineralogical and chemical compositions of the Be-rich albite granite facies.

The ${ }^{207} \mathrm{U}-{ }^{235} \mathrm{~Pb}$ data of $561 \pm 4$ Ma represent the crystallization age of the Be-rich albite granite, intrusive into the basement rocks (Caicó Complex) at the end of the Brasiliano orogeny (Ediacaran period). This record, then, becomes part of the set of older ages available in literature for $\mathrm{Nb}-\mathrm{Ta}( \pm \mathrm{Be}-\mathrm{Li}-\mathrm{Sn})$ granitic pegmatite from the Seridó Belt, linked to homogeneous LCT granitic pegmatite category, associated with granites from G3 phase (Jardim de Sá et al. 1981), and probably emplaced during transpression event. On the other hand, the ${ }^{40} \mathrm{Ar} /{ }^{39} \mathrm{Ar}$ data $($ plateau age $=553 \pm 4 \mathrm{Ma}$ ) point to the closure time for the metasomatic event responsible for the nucleation and growth of emerald crystals. The short interval time between $\mathrm{U}-\mathrm{Pb}$ and $\mathrm{Ar}-\mathrm{Ar}$ data indicates an intense, but not protracted, metasomatic history (Santiago et al. 2018), probably due to the low volume of intrusive magma.

\section{ACKNOWLEDGEMENTS}

This research had financial support from the Brazilian National Council of Technological and Scientific Development (CNPq - Project No. 308312/2014/7), the Geology Postgraduate Program of the University of Brasília (UnB) and the Precambrian Metallogeny Research Group of the IG-UnB/CNPq. Special thanks to the Brazilian Coordination for Improvement of Higher Education Personnel (CAPES) for the scholarship granted to the first author. The authors are also grateful to geologist Luiz Rodrigues Neto (Nosso Senhor do Bonfim Mining Company) for his support during fieldwork. We also thank the anonymous reviewers whose comments helped improve the final version of this manuscript.

\section{AUTHORS' CONTRIBUTION}

Manuscript ID: 20190081. Received on: 08/30/2019. Approved on: 10/31/2019.

J. S. acted in collecting and processing data, from field work to the conception of the scientific article. The information presented is part of his Master Thesis. V.S. worked in the collection and processing of data, from field work to the conception of the scientific article, acted as advisor and research coordinator. E. D. participated in the stage of treatment and interpretation of geochronological information, as well as for the discussion and interpretation on the regional geological setting. C.O. participated in the discussion of the geological model presented for the deposit. Competing interests: The authors declare no competing interests.

\section{REFERENCES}

Agrawal V.N. 1992. Relations between pegmatite emplacements and tectono-metamorphic events in the Seridó Group, northeastern Brazil. Revista Brasileira de Geociências, 22(1):43-46.

Almeida F.F.M., Hasui Y., Brito Neves B.B., Fuck R.A. 1981. Brazilian structural provinces: an introduction. Earth-Science Reviews, 17(1-2):1-29. https://doi.org/10.1016/0012-8252(81)90003-9

Alt J.C. \& Shanks W.C. 2003. Serpentinization of abyssal peridotites from the MARK area, Mid-Atlantic Ridge: Sulfur geochemistry and reaction modeling. Geochimica et Cosmochimica Acta, 67(4):641-653. https://doi. org/10.1016/S0016-7037(02)01142-0
Andrianjakavah P.R., Salvi S., Béziat D., Rakotondrazafy M., Giuliani G. 2009. Proximal and distal styles of pegmatite-related metasomatic emerald mineralization at Ianapera, southern Madagascar. Mineralium Deposita, 44(7):817-835. http://dx.doi.org/10.1007/ s00126-009-0243-5

Angelim L.A.A., Nesi J.R., Torres H.H.F., Medeiros V.C., Santos C.A., Junior J.P.V., Mendes V.A. 2006. Geological and Mineral Resources of the State of Rio Grande do Norte Project. Geology of Brazil Program (PGB). Geological Mapping, 1:500.000 scale. Recife (Brazil), MMEFAPERN, $76 \mathrm{p}$. 
Araújo M.N.C., Alves da Silva F.C., Jardim de Sá E.F. 2001. Pegmatite Emplacement in the Seridó Belt, Northeastern Brazil: Late Stage Kinematics of the Brasiliano Orogen. Gondwana Research, 4(1):75-85. https://doi. org/10.1016/S1342-937X(05)70656-0

Araújo M.N.C., Vasconcelos P.M., Alves da Silva F.C., Jardim de Sá E.F., Sá J.M. 2005. ${ }^{40} \mathrm{Ar} /{ }^{39} \mathrm{Ar}$ geochronology of gold mineralization in Brasiliano strike-slip shear zones in the Borborema province, NE Brazil. Journal of South American Earth Sciences, 19(4):445-460. https://doi.org/10.1016/j.jsames.2005.06.009

Ballouard C.,PoujolM.,BoulvaisP., BranquetY., Tartèse R., VigneresseJ-L.2016.NbTa fractionation in peraluminous granites: A marker of the magmatic-hydrothermal transition. Geology, 44(3):231-234https://doi.org/10.1130/G37475.1

Baumgartner R., Rolf L., Romer R.L., Moritz R., Sallet R., Chiaradia M. 2006. Columbite-tantalite-bearing granitic pegmatites from the Seridó Belt, northeastern Brazil: genetic constraints from $\mathrm{U}-\mathrm{Pb}$ dating and $\mathrm{Pb}$ isotopes. Canadian Mineralogist, 44(1):69-86. https://doi.org/10.2113/gscanmin.44.1.69

Beurlen H., Barreto S., Martin R., Melgarejo J., Silva M.R.R., Souza Neto J.A. 2009. The Borborema Pegmatite Province, NE-Brasil revisited. Estudos Geológicos, 19(2):62-66. http://dx.doi.org/10.18190/1980-8208/ estudosgeologicos.v19n2p62-66

Beurlen H.,Silva M.R.R., Castro C.2001.Fluid inclusion microthermometryin $\mathrm{Be}-\mathrm{Ta}-(\mathrm{Li}-\mathrm{Sn})$ - bearing pegmatites from the Borborema Province, Northeast Brazil. Chemical Geology, 173(1-3):107-123.

Beurlen H., Thomas R., Silva M.R.R., Müller A., Rhede D., Soares D.R. 2014. Perspectives for Li- and Ta-Mineralization in the Borborema Pegmatite Province, NE-Brazil: A review. Journal of South American Earth Sciences, 56:110-127. http://dx.doi.org/10.1016/j.jsames.2014.08.007

Boynton W.V. 1984. Cosmogeochemistry of the rare earth elements: meteorite studies. In: Henderson, P. (Ed.). Rare Earth Element Geochemistry. New York, Elsevier, p. 63-114

Brito Neves B.B., Fuck R.A., Pimentel M.M. 2014. The Brasiliano collage in South America: a review. Brazilian Journal of Geology, 44(3):493-518. http://dx.doi.org/10.5327/Z2317-4889201400030010

Brito Neves B.B., Santos E.J., Van Schmus W.R. 2000. The tectonic history of the Borborema Province. In: Cordani U.G., Milani E.J., Thomaz Filho A., Campos D.A. (Eds.). Tectonic evolution of South America. Rio de Janeiro, 31st International Geological Congress, 2:151-182.

Bühn B., Pimentel M.M., Matteini M., Dantas E.L. 2009. High spatial resolution analysis of $\mathrm{Pb}$ and $\mathrm{U}$ isotopes for geochronology by laser ablation multi-collector inductively coupled plasma mass spectrometry (LA-MCICP-MS). Anais da Academia Brasileira de Ciências, 81(1):1-16. http:// dx.doi.org/10.1590/S0001-37652009000100011

CabyR.,Arthaud M.,Archanjo C.J. 1995.Lithostratigraphyand petrostructural characterization of supracrustal units in the Brasiliano Belt of Northeastern Brazil: geodynamic implications. Journal of South American Earth Sciences, 8(3-4):235-246. https://doi.org/10.1016/0895-9811(95)00011-4

Caby R., Sial A.N., Arthaud M., Vauchez A. 1991. Crustal evolution and the Brasiliano orogeny in Northeast Brazil. In: Dallmeyer R.D. \& Lécorché J.C.P.L. (Eds.). The West African Orogens and Circum-Atlantic Correlatives. Berlin, Springer Verlang, p. 373-397.

Carcangiu G., Palomba M., Tamanini 1997. REE-bearing minerals in the albitites of central Sardinia, Italy. Mineralogical Magazine, 61 (405):271-283. https://doi.org/10.1180/minmag.1997.061.405.10

Cavalcante R., Cunha A.L.C., Oliveira R.G., Medeiros V.C., Dantas A.R., Costa A.P., Lins C.A.C., Larizzatti J.H. 2016. Metalogenesis of the Brazilian Mineral Provinces: east Seridó area, northeastern Borborema Province (Rio Grande do Norte and Paraiba states). Brazil, Geology of Brazil Program (PGB), MMESGB/CPRM (Brazil), Brazilian Minerals Provinces Series, n. 8, 103 p.

Cavalcanti Neto M.T.O. \& Barbosa R.V.N. 2007. The emeralds from Lajes, Caiçara do Rio dos Ventos and São Tomé/RN. Holos, 2:92-104. https://doi. org/10.15628/holos.2007.103

Chiaradia M., Schaltegger U., Spikings R., Wotzlaw J-F., Ovtcharova M. 2013. How accurately can we date the duration of magmatic-hydrothermal events in porphyry systems?: an invited paper. Economic Geology, 108(4):565-584. https://doi.org/10.2113/econgeo.108.4.565

Cosca M., Stunitz H., Bourgeix A.-L., Lee J.P. $2011 .{ }^{40} \mathrm{Ar}^{*}$ loss in experimentally deformed muscovite and biotite with implications for ${ }^{40} \mathrm{Ar} /{ }^{39} \mathrm{Argeoch}$ ronology of naturally deformed rocks. Geochimica et Cosmochimica Acta, 75 (24):77597778. https://doi.org/10.1016/j.gca.2011.10.012
Dalrymple G.B., Alexander Jr. E.C., Lanphere M.A., Kraker G.P. 1981. Irradiation of samples for ${ }^{40} \mathrm{Ar} /{ }^{39} \mathrm{Ar}$ dating using the Geological Survey TRIGA Reactor. Professional Paper, n. 1176, 55 p. https://doi.org/10.3133/pp1176

Dantas E.L. 1997. $\mathrm{U} / \mathrm{Pb}$ and $\mathrm{Sm} / \mathrm{Nd}$ geocronology of the Archean and Paleoproterozoic terraine from São José do Campestre Massif, NE Brazil. $\mathrm{PhD}$ Thesis, Geoscience Institute, Universidade Estadual Paulista "Júlio de Mesquita Filho", Rio Claro, 211 p.

Dantas E.L., Souza Z.S., Wernick E., Hackspacher P.C., Martin H., Xiaodong D., Li J.-W. 2013. Crustal growth in the 3.4-2.7 Ga São José de Campestre Massif, Borborema Province, NE Brazil. Precambrian Research, 227:120156. https://doi.org/10.1016/j.precamres.2012.08.006

Dantas E.L., Van Schmus W.R., Hackspacher P.C., Fetter A.H., Neves B.B.B., Cordani U., Nutman A., Williams I.S. 2004. The 3.4-3.5 GA São José do Campestre Massif, NE Brazil : remnants of the oldest crust in South America. Precambrian Research, 130(1-4):113-137. http://dx.doi. org/10.1016/j.precamres.2003.11.002

Dantas R.C., Dantas E.L., Oliveira C.G. 2014. Geochemistry and geochronology (U-Pb and Sm-Nd) of the Archean rocks from W-Au Bonfim deposit (RN), Seridó Belt, Borborema Province. In: Brazilian Congress of Geology, 47., Salvador. Procedures ... Salvador, SBG, p. 1914-1914. CD-ROM.

Debon F. \& Le Fort P. 1983. A chemical-mineralogical classification of common plutonic rocks and associations. Transactions of Royal Society of Edinburgh: Earth Sciences, 73(3):135-149. https://doi.org/10.1017/S0263593300010117

Deckart K., Clark A.H., Celso A.A., Ricardo V.R., Bertens A., Mortensen J.K., Fanning M. 2005. Magmatic and hydrothermal chronology of the giant Río Blanco porphyry copper deposit, central Chile: Implications of an integrated U-Pb and ${ }^{40} \mathrm{Ar} /{ }^{39} \mathrm{Ar}$ database. Economic Geology, 100(5):905934. https://doi.org/10.2113/gsecongeo.100.5.905

Deer W.A., Howie R.A., Zussman J. 1992. An introduction to the rock-forming minerals. New York, Longman Sci. \& Tec., John Wiley \& Sons, 694 p.

Engvik A.K., Putnis A., Fitz-Gerald J.D., Austrheim H. 2008. Albitization of granitic rocks: the mechanism of replacement of oligoclase by albite. Canadian Mineralogist, 46(6):1401-1415. https://doi.org/10.3749/ canmin.46.6.1401

Ferreira V.P., Sial A.N., Jardim de Sá E.F. 1998. Geochemical and isotopic signatures of Proterozoic granitoids in terrenes of the Borborema structural province, northeastern Brazil. Journal of South America Earth Sciences, 11 (5):439-455. https://doi.org/10.1016/S0895-9811(98)00027-3

Giuliani G., Groat L.A., Marshall D., Fallick A.E., Branquet Y. 2019. Emerald Deposits: A Review and Enhanced Classification. Minerals, 9(2):105. https://doi.org/10.3390/min9020105

Giuliani G., Silva L.J.H.D., Couto P. 1990. Origin of emerald deposits of Brazil. Mineralium Deposita, 25(1):57-64. https://doi.org/10.1007/BF03326384

Groat L.A., Giuliani G., Marshall D.D., Turner D. 2008. Emerald deposits and occurrences: A review. Ore Geology Reviews, 34(1-2):87-112. https:// doi.org/10.1016/j.oregeorev.2007.09.003

Groat L.A., Marshall D.D., Giuliani G., Murphy D.C., Piercey S.J., Jambor J.L., Mortensen J.K., Ercit T.S., Gault R.A., Mattey D.P., Schwarz D., Maluski H, Wise M.A., Wengzynowski W., Eaton D.W. 2002. Mineralogical and geochemical study of the Regal Ridge Emerald Showing, Southeastern Ukon. The Canadian Mineralogist, 40(5):1313-1338. https://doi. org/10.2113/gscanmin.40.5.1313

Grundmann G. \& Morteani G. 1989. Emerald mineralization during regional metamorphism: the Habachtal (Austria) and Leydsdorp (Transvaal, South Africa) deposits. Economic Geology, 84(7):1835-1849. https://doi.org/10.2113/gsecongeo.84.7.1835

Haapala I. 1997. Magmatic and postmagmatic processes in Tin-mineralized granites: topaz-bearing leucogranite in the Eurajoki Rapakivi Granite Stock, Finland. Journal of Petrology, 38(12):1645-1659. https://doi.org/10.1093/ petroj/38.12.1645

Hackspacher P.C., Dantas E.L., Brito Neves B.B., Legrand J.M. 1997. Northwestern overthrusting and related lateral escape during the Brasiliano Orogeny north of the Patos Lineament, Borborema Province, northeast Brazil. International Geologv Review, 39(7):609-620. http://dx.doi. org/10.1080/00206819709465291

Harrison T.M., Célérier J., Aikman A.B., Hermann J., Heizler M.T 2009. Diffusion of ${ }^{40} \mathrm{Ar}$ in muscovite. Geochimica et Cosmochimica Acta, 73(4):1039-1051. https://doi.org/10.1016/j.gca.2008.09.038 
Jardim de Sá E.F. 1994. Seridó Belt (Borborema Province, NE Brazil) and its geodynamic meaning in the Brasiliano/Pan-African cycle. PhD Thesis, Instituto de Geociências, Universidade de Brasília, Brasília, 803 p

Jardim de Sá E.F., Fuck R.A., Macedo M.H.F., Peucat J.J., Kawashita K., Souza Z.S., Bertrandt J.M. 1995. Pre-Brasiliano orogenic evolution in the Seridó Belt, NE Brazil: conflicting geochronological and structural data. Revista Brasileira de Geociências, 25 (4):307-314.

Jardim de Sá E.F., Legrand J.M., McReath I. 1981. Stratigraphy of granitoid rocks in the Seridó region (RN-PB): Based on structural criteria. Revista Brasileira de Geociências, 11:50-57.

Jiang S-Y, Wang R-C, Xu X-S, Zhao K-D. 2005. Mobility of high field strength elements (HFSE) in magmatic-, metamorphic-, and submarinehydrothermal systems. Physics and Chemistry of the Earth, 30(17-18):10201029. http://dx.doi.org/10.1016/j.pce.2004.11.004

Kaur P., Chaudhri N., Hofmann A.W., Raczek I., Okrusch M., Skora S., Baumgartner L.P. 2012. Two-stage, extreme albitization of A-type granites from Rajasthan, NW India. Journal of Petrology, 53 (5):919-948. https:// doi. org/10.1093/petrology/egs003

Laurs B.M., Dilles J.H., Snee L.W. 1996. Emerald mineralization and metasomatism of amphibolite, Khaltaro granitic pegmatite - hydrothermal vein system, Haramosh Mountains, northern Pakistan. The Canadian Mineralogist, 34(6): 1253-1286.

Lobato L.M. \& Fyfe W. 1990. Metamorphism, metasomatism, and mineralization at Lagoa Real, Bahia, Brazil. Economic Geology, 85(5):968989. https://doi.org/10.2113/gsecongeo.85.5.968

Ludwig K.R. 2003. User's Manual for Isoplot/Ex, Version 3.0, a geochronological toolkit for Microsoft Excel. Berkeley, Berkeley Geochronology Center, Special Publication, v. 4.

Maniar P.D. \& Piccoli P.M. 1989. Tectonic discrimination of granitoids. Geological Society of America Bulletin, 101(5):635-643. https://doi. org/10.1130/0016-7606(1989)101\%3C0635:TDOG\%3E2.3.CO;2

McDougall I. \& Harrison T.M. 1988. Geochronology and Thermochronology by the ${ }^{40} \mathrm{Ar} /{ }^{39} \mathrm{Ar}$ Method. New York, Oxford University Press, $212 \mathrm{p}$.

Nascimento M.A.L., Antunes A.F., Galindo A.C., Jardim de Sá E.F., Souza Z.S. 2000. Geochemical Signature of the Brasiliano-Age Plutonism in the Seridó Belt, Northeastern Borborema Province (NE Brazil). Revista Brasileira de Geociências, 30(1):161-164.

Neves S.P. 2003. Proterozoic history of the Borborema Pronvince (NE Brazil): Correlation with neighboring cratons and Pan-African belts and implications for the evolution of western Gondwana. Tectonics, 22(4):5-14. http://doi.org/10.1029/2001TC001352

Oliveira J.A.P. \& Ali S.H. 2011. Gemstone mining as a development cluster: a study of Brazil's emerald mines. Resources Policy, 36(2):132-141. https:// doi.org/10.1016/j.resourpol.2010.10.002

Petersson J. \& Eliasson T. 1997. Mineral evolution and element mobility during episyenitization (dequartzification) and albitization in the postkinematic Bohus granite, southwest Sweden. Lithos, 42(1-2):123-146. https://doi.org/10.1016/S0024-4937(97)00040-6

Roddick J.C. 1983. High precision intercalibration of ${ }^{40} \mathrm{Ar} /{ }^{39} \mathrm{Ar}$ standards. Geochimica et Cosmochimica Acta, 47(5):887-898. https://doi. org/10.1016/0016-7037(83)90154-0

Salvi S., Fontan F., Monchoux P., Williams-Jones A.E., Moine B. 2000. Hydrothermal Mobilization of High Field Strength Elements in Alkaline Igneous Systems: Evidence from the Tamazeght Complex (Morocco).Economic Geology, 95(3):559-576. https://doi.org/10.2113/gsecongeo.95.3.559

Santiago J.S. 2017. Emerald mineralization during the Brasiliano Orogeny in northeastern Brazil: The case of the Fazenda Bonfim deposit, State of Rio Grande do Norte. Masters Dissertation, Geology Post-graduation Program, Geoscience Institute, Brasília University, Brasília, 32 p.

Santiago J.S., Souza V.S., Filgueiras B.C., Jiménez F.A.C. 2018. Emerald from the Fazenda Bonfim Deposit, northeastern Brazil: chemical, fluid inclusions and oxygen isotope data. Brazilian Journal of Geology, 48(3):457-472. https://doi.org/10.1590/2317-4889201820170130

Santos T.J.S., Fetter A.H., Hackspacher P.C., Van Schmus W.R., Nogueira Neto J.A. 2008. Neoproterozoic tectonic and magmatic episodes in the NW sector of Borborema Province, NE Brazil, during assembly of Western Gondwana. Journal of South American Earth Sciences, 25(3):271-284. https://doi.org/10.1016/j.jsames.2007.05.006
Scholz R., Romano A.W., Belotti F.M., Chaves M.L.S.C. 2010. Geochemical prospection of beryl emerald variety in the Fazenda Bonfim region (Lajes, RN). Geociências, 29(4):613-621.

Schwarz D. \& Giuliani G. 2001. Emerald deposits a review. The Australian Gemmologist, 21:17-23.

Sheard E.R., Williams-Jones A.E., Heiligmann M., Pederson C., Trueman D.L. 2012. Controls on the Concentration of Zirconium, Niobium, and the Rare Earth Elements in the Thor Lake Rare Metal Deposit, Northwest Territories, Canada. Economic Geology, 107(1):81-104. https://doi. org/10.2113/econgeo.107.1.81

Sial A.N. 1986. Granite-types in northeast Brazil: current knowledge. Revista Brasileira de Geociências, 16(1):54-72.

Silva M.R.R., Höll R., Beurlen H. 1995. Borborema Pegmatite Province: geological and geochemical characteristics. Journal of South American Earth Sciences, 8(3-4):355-364. https://doi. org/10.1016/0895-9811(95)00019-C

Silveira C.L.P., Schorscher H.D., Miekeley N. 1991. The geochemistry of albitization and related uranium mineralization, Espinharas, Paraiba (PB), Brazil. Journal of Geochemical Exploration, 40(1-3):329-347. https://doi. org/10.1016/0375-6742(91)90046-W

Soares D.R. 2004. Contribution to petrology of the rare-elements and elbaite gemstone from Borborema Pegmatite Province, northeastern Brazil. $\mathrm{PhD}$ thesis, Geoscience and Technology Center, Pernambuco Federal University, Recife, $170 \mathrm{p}$.

Souza Neto J.A., Legrand J.M., Volfinger M., Pascal M.-L., Sonnet P. 2008. W-Au skarns in the Neo-Proterozoic Seridó Belt, Borborema Province in northeastern Brazil: an overview with emphasis on the Bonfim deposit. Mineralium Deposita, 43(2):185-205. https://doi.org/10.1007/ s00126-007-0155-1

Souza Z.S., Martin H., Peucat J.J., Jardim de Sá E.F., Macedo M.H.F. 2007. Calcalkaline magmatism at the Archean-Proterozoic transition: the Caicó Basament Complex (NE Brazil). Journal of Petrology, 48(11):2149-2185. https://doi.org/10.1093/petrology/egm055

Steiger R.H. \& Jäger E. 1977. Subcommission on geochronology: Convention on the use of decay constants in geo- and cosmochronology. Earth and Planetary Science Letters, 36(3):359-362. https://doi. org/10.1016/0012-821X(77)90060-7

Thompson R.N. 1982. Magmatism of the British Tertiary volcanic province. Scottish Journal of Geology, 18:49-107. https://doi.org/10.1144/ sig18010049

Van Schmus W.R., Brito Neves B.B., Hackspacher P., Babinski M. 1995. $\mathrm{UPb}$ and $\mathrm{SmNd}$ geochronolgic studies of eastern Borborema Province, northeastern Brazil: initial conclusions. Journal of South American Earth Sciences, 8(3-4):267-288.https://doi.org/10.1016/0895-9811(95)00013-6

Van Schmus W.R., Brito Neves B.B., Williams I.S., Hackspacher P., Fetter A.H., Dantas E.L., Babinski M. 2003. The Seridó Group of NE Brazil, a late Neoproterozoic pre- to syn-collisional basin in West Gondwana: insights from SHRIMP U-Pb detrital zircon ages and $\mathrm{Sm}-\mathrm{Nd}$ crustal residence (TDM) ages. Precambrian Research, 127(4):287-327. https://doi. org/10.1016/S0301-9268(03)00197-9

Vapnik Y.E., Moroz I., Roth M., Eliezri I. 2006. Formation of emeralds at pegmatite-ultramafic contacts based on fluid inclusions in Kianjavato emerald, Mananjary deposits, Madagascar. Mineralogical Magazine, 70(2):141-158. https://doi.org/10.1180/0026461067020320

Vauchez A., Neves S., Caby R., Corsini R., Egydio-Silva M., Arthaud M., Amoro V. 1995. The Borborema shear zone system, NE Brazil. Journal of South American Earth Sciences, 8(3-4):247-266. https://doi. org/10.1016/0895-9811(95)00012-5

Verdel C., Pluijm B.A.V.D., Niemi N. 2012. Variation of illite/muscovite ${ }^{40} \mathrm{Ar} /{ }^{39} \mathrm{Ar}$ age spectra during progressive low-grade metamorphism: an example from the US Cordillera. Contribution to Mineralogy and Petrology, 164(3):521-536. https://doi.org/10.1007/s00410-012-0751-7

Zhang Y.,Dostal J., ZhaoZ.,Liu C., Guo Z.2011. Geochronology, geochemistry and petrogenesis of mafic and ultramafic rocks from Southern Beishan area, NW China: Implications for crust-mantle interaction. Gondwana Research, 20(4):816-830. https://doi.org/10.1016/j.gr.2011.03.008

Zwaan J.C.H., Jacob D.E., Häger T., Cavalcanti Neto M.T.O., Kanis J. 2012. Emeralds from the Fazenda Bonfim region, Rio Grande do Norte, Brazil. Gems \& Gemology, 48(1):2-17. https://doi.org/10.5741/GEMS.48.1.2 